\title{
Decreased TRPM7 inhibits activities and induces apoptosis of bladder cancer cells via ERK1/2 pathway
}

\author{
Rui Cao ${ }^{1, *}$, Zhe Meng ${ }^{1, *}$, Tongzu Liu ${ }^{1}$, Gang Wang ${ }^{1}$, Guofeng Qian ${ }^{2}$, Tingting $\mathrm{Cao}^{3}$, \\ Xinyuan Guan ${ }^{3}$, Hancai Dan ${ }^{4}$, Yu Xiao ${ }^{1,5}$, Xinghuan Wang ${ }^{1}$ \\ ${ }^{1}$ Department of Urology, Zhongnan Hospital of Wuhan University, Wuhan, China \\ ${ }^{2}$ Department of Endocrinology, The First Affiliated Hospital of Zhejiang University, Hangzhou, China \\ ${ }^{3}$ Department of Clinical Oncology, Li Ka Shing Faculty of Medicine, University of Hong Kong, Hong Kong \\ ${ }^{4}$ Greenebaum Cancer Center, School of Medicine, University of Maryland, Baltimore, MD, USA \\ ${ }^{5}$ Center for Medical Science Research, Zhongnan Hospital of Wuhan University, Wuhan, China \\ *These authors contributed equally to this work \\ Correspondence to: Yu Xiao, email: yu.xiao@whu.edu.cn \\ Xinghuan Wang, email: wangxinghuan@whu.edu.cn
}

Keywords: TRPM7, bladder cancer, apoptosis, MAPK, AKT

Received: March 29, 2016

Accepted: September 13, 2016

Published: September 20, 2016

\section{ABSTRACT}

Transient receptor potential melastatin 7 (TRPM7) functions as a $\mathrm{Mg}^{2+} / \mathrm{Ca}^{2+}$ permeable channel fused with a kinase domain and regulates various physical processes and diseases. However, its effects on pathogenesis of human bladder cancer ( $\mathrm{BCa}$ ) has not been clarified yet. Our microarray analysis has suggested that calcium signaling pathway is connected with bladder cancer via MAPK pathway. Therefore, we aim to investigate the mechanism of TRPM7 in BCa tumorigenesis by using BCa tissues compared with normal bladder epithelium tissues, as well as using distinct BCa cell lines (EJ, 5637 and T24). We observed increased TRPM7 expression and dysregulation of proteins involved in Epithelial-Mesenchymal Transition (EMT) in BCa tissues. Moreover, knockdown of TRPM7 in BCa cells reversed the EMT status, accompanied by increase of reactive oxygen species (ROS). Furthermore, TRPM7 deficiency could inhibit BCa cell proliferation, migration and invasion, as well as induce $p-E R K 1 / 2$ and suppress PI3K/AKT at the protein level. Downregulation of TRPM7 promoted cell cycle arrest at G0/G1 phase and apoptosis in vitro, which could be recovered by pre-treatment with $\mathrm{U} 0126$ to deactivate ERK1/2, suggesting a close correlation between TRPM7 and the MAPK signaling pathway. Furthermore, a NOD/SCID mouse model transplanted using the BCa cells was established, revealing delayed tumor growth by reduced protein activity and mRNA transcription of TRPM7 in vivo. Our results suggested TRPM7 might be essential for $\mathrm{BCa}$ tumorigenesis by interfering BCa cell proliferation, motility and apoptosis.

\section{INTRODUCTION}

Bladder cancer $(\mathrm{BCa})$ is one of the most common cancers worldwide [1]. Despite recent progress, the molecular mechanism underlying $\mathrm{BCa}$ pathogenesis remains to be further elucidated. Therefore, our group has generated a microarray analysis using total RNA isolated from several bladder cancer tissues comparing with normal bladder epithelium [2], suggesting calcium signaling pathway was linked with bladder cancer via MAPK signaling pathway, which was connected with cell cycle.

Mitogen-activated protein kinases (MAPKs) play a key role in signal transduction from cell membrane to nucleus in response to a wide range of stimuli and are involved in the regulation of cell proliferation [3], survival, differentiation [4] and apoptosis [5]. Importantly, aberrant regulation of MAPK could contribute to cancer 
and other human diseases, including bladder cancer $[6,7]$. Many studies have suggested that intracellular or extracellular calcium disorders might induce abnormal activation or deactivation of MAPK cascades $[8,9]$ and consequently initiate cancer development [10]. A recent publication using pathway network analyses revealed a major overlaps with various diseases and convergence upon MAPK and calcium signaling as well [11]. Studies using U0126, a selective MAPK kinase (MKK) inhibitor [12], have revealed a major effect on the deactivation of ERK1/2 [13] possibly even affecting MAPK-mediated mitochondrial-derived [14] and endoplasmic reticulum stress induced apoptosis [15].

Transient receptor potential melastatin 7 (TRPM7) is a member of "chanzymes", which function as a $\mathrm{Mg}^{2+}$ / $\mathrm{Ca}^{2+}$-permeable channel fused with a kinase. TRPM7 has been reported to be ubiquitously expressed in various human tissues [16-18], suggesting that it could be implicated in important physiological processes such as cellular $\mathrm{Mg}^{2+}$ homeostasis [18], cell viability and growth [19], anoxic neuronal cell death [20], and cell adhesion [21]. Recent studies indicated a close correlation between TRPM7 and cancer, demonstrating its involvement in retinoblastoma [22], gastric cancer [23], breast cancer [24-27], nasopharyngeal carcinoma [28], pancreatic cancer [29], prostate cancer [30], and ovarian carcinoma [31]. Our previous studies have suggested that knockdown of TRPM8, another important subtype of the TRPM family, could inhibit proliferation of osteosarcoma and prostate cancer cells [32, 33]. In addition, our studies have suggested that TRPM7 affects kidney injury [34], revealing a correlation between the TRPM family and cell ability [35], cell growth as well as Epithelial-Mesenchymal Transition (EMT) [36], which was involved in malignancy of tumor. Another publication has reported that during stress condition, such as brain ischaemia, TRPM7 could control the level of reactive oxygen species (ROS) [37], which could have a Cross Talk with the EMT [38]. TRPM7 has been reported to be expressed in human and mouse urothelium [39, 40], as well as in MBT-2 mouse bladder cancer cells and T24 human bladder cancer cells [41], but its effect and mechanism in human bladder cancer remain largely unknown. Therefore, we hypothesized that TRPM7, which is involved in the calcium signaling pathway, could affect bladder cancer by the MAPK signaling pathway to trigger $\mathrm{BCa}$ cell cycle arrest and apoptosis. We aim to identify the alteration of TRPM7 and related proteins involved in the EMT regulation using BCa tissues in vivo, and to observe its effects on EMT, cell migration/invasion, apoptosis and cell cycle in distinct $\mathrm{BCa}$ cell lines in vitro for a potential strategy of rescue experiment, as well as to analyze the influence of tumor growth using nude mice in vivo with deactivated TRPM7 and downregulated TRPM7 at transcriptional level.

\section{RESULTS}

\section{Microarray analysis revealed calcium and MAPK signaling pathways as central regulators in BCa development}

Three BCa tissues (stage II) and three normal bladder tissues were collected for alterations of mRNA by microarray analysis (Approval in Supplementary Information S1), suggesting 1338 genes (fold change $>1.5$ ) (Supplementary Information S2) and 146 signaling pathways were significantly affected in the BCa tissues (Supplementary Information S3). Using a GCBI analysis tool, a pathway network connected to $\mathrm{BCa}$ was generated (Figure 1), indicating that a calcium signaling pathway was correlated with BCa via the MAPK signaling pathway connected with cell cycle regulation, as well as a central role of calcium and MAPK signaling pathways involved in the development of $\mathrm{BCa}$. In addition, by annotation and overrepresentation analysis using our raw microarray data and DAVID database, we observed the genes involved in calcium signaling pathway were altered (Supplementary Figure S1A), accompanied by significantly upregulation of $C A L M, C a N$ and $C A M K$ under the deficiency of TRPM7 in vitro (Supplementary Figure S1B-S1C). Therefore, we would like to investigate the alterations of the genes and proteins related with the pathways using bladder tissues and distinct $\mathrm{BCa}$ cell lines.

\section{Induction of TRPM7 and dysregulation of EMT markers in BCa tissues}

Immunofluorescence staining using ten $\mathrm{BCa}$ tissues and ten normal bladder tissues revealed a strong increase of OCT-4 in the cytoplasmic region of the $\mathrm{BCa}$ tissues (representative staining in Figure 2C-2D). Distinct human $\mathrm{BCa}$ cell lines (from high malignancy to low malignancy: T24, 5637, EJ, UM-UC-3, BIU-87, RT-4) and immortalized normal uroepithelial cell line (SV-HUC-1) exhibited a downregulation tendency of OCT-4 by Western blot analysis (Figure 2B), suggesting OCT-4 could be a marker for bladder cancer. qRT-PCR revealed that transcription of TRPM7 was upregulated in the $\mathrm{BCa}$ tissues compared with the normal bladder tissues (Figure 2A). TRPM7 was also induced in cytomembrane of the OCT4-positive cells in the BCa tissues (representative staining in Figure 2E a-b). Immunofluorescence analysis also suggested that distribution of proteins (E-cadherin and N-cadherin) involved in EMT process was strongly altered (representative staining in Figure 2E c-f). We observed a reduction of E-cadherin (Figure 2E c-d) and an increase of $\mathrm{N}$-cadherin (Figure 2E e-f) in the OCT-4 positive cells in BCa tissues. 


\section{Downregulation of $T R P M 7$ reversed dysregulation of EMT markers in vitro}

To investigate the effects of TRPM7 in $\mathrm{BCa}$, a model of TRPM7 deficiency in distinct $\mathrm{BCa}$ cell lines (T24, EJ and 5637) was established by siRNA transfection. The knockdown efficiency of the siRNA was validated by qRT-PCR (Figure 3B), Western blot analysis (Figure $3 \mathrm{~A}$ ), and immunofluorescence staining (representative staining in Figure 3C), indicating TRPM7 was remarkably silenced both at gene transcription and translation levels in the three $\mathrm{BCa}$ cells transfected by the siRNA. In contrast to the decrease of E-cadherin and increase of $\mathrm{N}$-cadherin noticed in the $\mathrm{BCa}$ tissues (Figure 2E c-f). Knockdown of TRPM7 triggered strong upregulation of the epithelial marker E-cadherin and considerable downregulation of the two mesenchymal markers N-cadherin and Vimentin, revealed by Western blot analysis (Figure 3D) and immunofluorescence staining (representative staining in Figure 3E-3G), suggesting reduced TRPM7 could alleviate malignancy of the BCa cells.



Figure 1: Microarray analysis using mRNA isolated from BCa tissues and normal bladder epithelium tissues. From the microarray results, 1338 genes (fold change $>1.5$, Supplementary Information 2) and 146 signaling pathways (Supplementary Information 3) were screened out. Gene ontology (GO) and Go-map network analysis by using the GCBI analysis tool suggested the calcium signaling pathway was at a central position associated with bladder cancer via the MAPK signaling pathway. 


\section{Induction of ROS in BCa cells with TRPM7 deficiency}

The status of ROS in the BCa cells (T24 and EJ) were measured by flow cytometry analysis (Supplementary Figure S2A) and fluorescence staining (Supplementary Figure S2C). Statistical analysis (Supplementary Figure S2B) revealed a significantly increase ROS in the SiTRPM7-treated $\mathrm{BCa}$ cells by the flow cytometry measurement. Western blot analysis indicated an increased protein abundance of Catalase and SOD2 in the $\mathrm{BCa}$ cells with downregulated TRPM7 (Supplementary Figure S2D).

\section{TRPM7 deficiency impaired BCa cells motility and invasion via the PI3K/AKT pathway}

The relationship between TRPM7 and BCa cell motility and invasion was investigated using transwell and wound healing assays. Transwell assay suggested that knockdown of TRPM7 in BCa cells could reduce cell migration and invasion (Figure 4A), which was confirmed by statistically analysis in Figure 4B-4C. Moreover, wound healing assay revealed that TRPM7 deficiency in $\mathrm{BCa}$ cells could reduce the number of migrated cells (Figure 4D). The gap closure (\%) was statistically analyzed (Figure 4E). Furthermore, downregulation of p-FAK and MMP2/9 in BCa cells with SiTRPM7 was noticed (Figure 4F). Interestingly, we have also observed the PI3K/AKT signaling pathway, a downstream of FAK [42], was affected by TRPM7 deficiency as well, revealing a strong reduction of p-PI3K and p-AKT (Figure 4F).

\section{Knockdown of TRPM7 triggered G0/G1 phase cell cycle arrest and apoptosis in the $\mathrm{BCa}$ cells}

CCK-8 assay revealed that TRPM7 deficiency induced inhibition of cell growth, compared with the parental and siCON cells (Figure 5A). To better understand the underlying mechanism, the effects of TRPM7 on cell cycle (Figure 5B) and apoptosis (Figure 6A-6B) were analyzed using flow cytometry analysis. Compared with the control cells, knockdown of TRPM7 in the BCa cells triggered cell cycle arrest at G0/G1 phase (statistically analyzed in Figure 5B) as well as a reduction in the
A



B
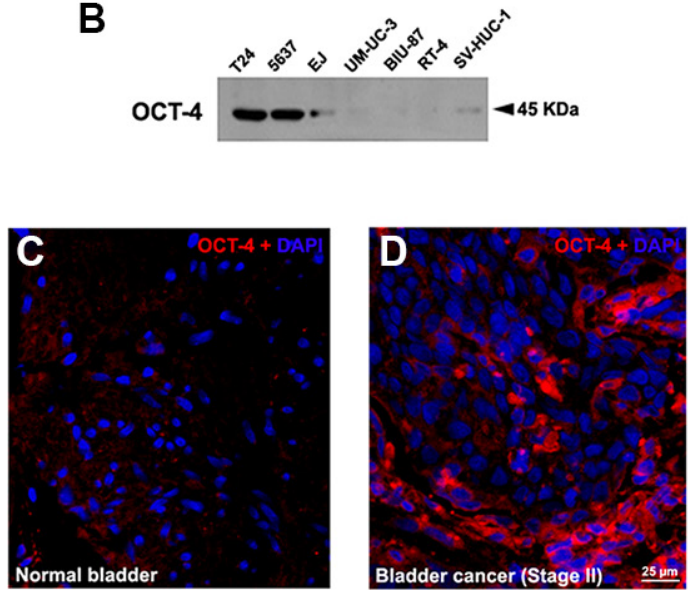
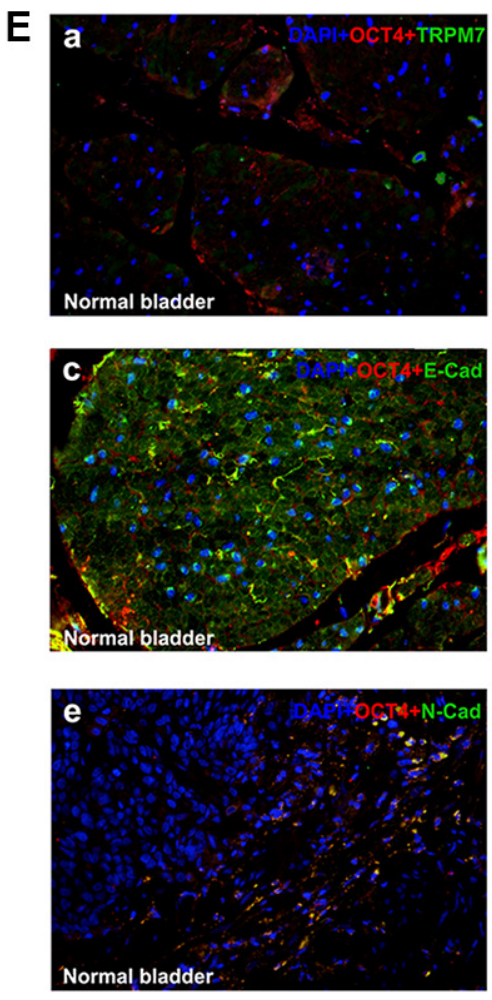
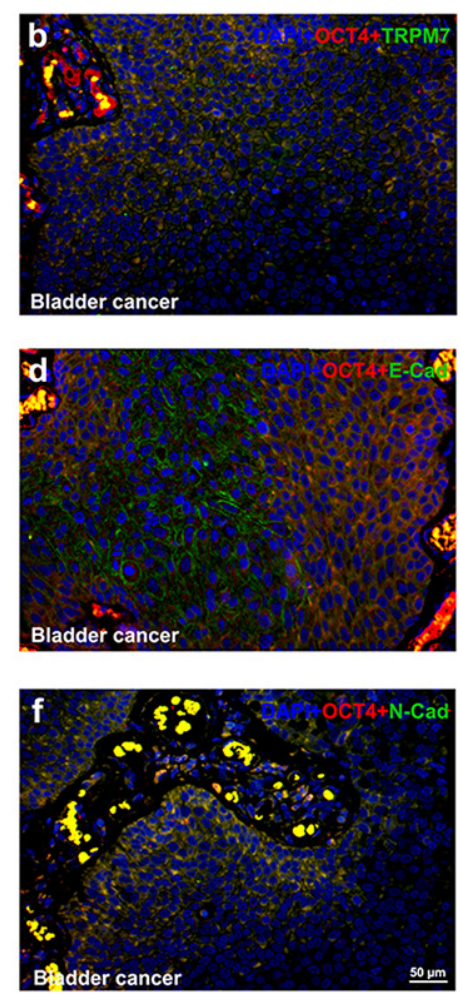

Figure 2: TRPM7 is upregulated in the BCa tissues and correlated with EMT markers. (A) qRT-PCR analysis of relative gene expression of TRPM7 in total RNA isolated from ten BCa tissues at stage II, comparing with ten normal bladder tissues. Significance of TRPM7 expression difference was analyzed using $T$-test. ${ }^{*} p<0.05$. (B) Western blot analysis of OCT-4 protein abundance in the human BCa cell lines (T24, 5637, EJ, UM-UC-3, BIU-87, RT-4) and immortalized normal uroepithelial cell line (SV-HUC-1), cell types and protein masses were indicated. (C-D) Representative immunofluorescence staining of OCT-4 (red) in the BCa tissue (D) comparing with the normal bladder tissue (C). Nuclears were stained by DAPI (blue). The images were photographed by fluorescence microscopy. The scale bar for $\mathrm{C}$ and $\mathrm{D}$ is $25 \mu \mathrm{m}$. (E) Representative double immunofluorescence staining of TRPM7, E-cadherin and N-cadherin (green) in the BCa tissues (b, d, f) comparing with normal bladder tissues (a, c, e). OCT-4 (red) was used as a marker of BCa cells, suggesting upregulation of TRPM7 and N-cadherin in the OCT-4 positive BCa cells (b and f), whereas a downregulation of E-cadherin (d). Nuclears were stained by DAPI (blue). The scale bar for $\mathrm{E}$ (a-f) is $50 \mu \mathrm{m}$. 
proportion of cells in S phase. Indeed, cell cycle related proteins such as Cyclin D1 and CDK2/4 were decreased in the BCa cells with TRPM7 knockdown (Figure 5C). Moreover, TRPM7 deficiency resulted in a significant increase of the apoptotic BCa cells (Figure 6A-6B). We

A

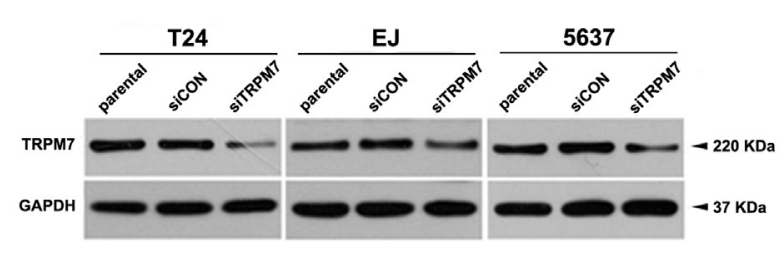

B

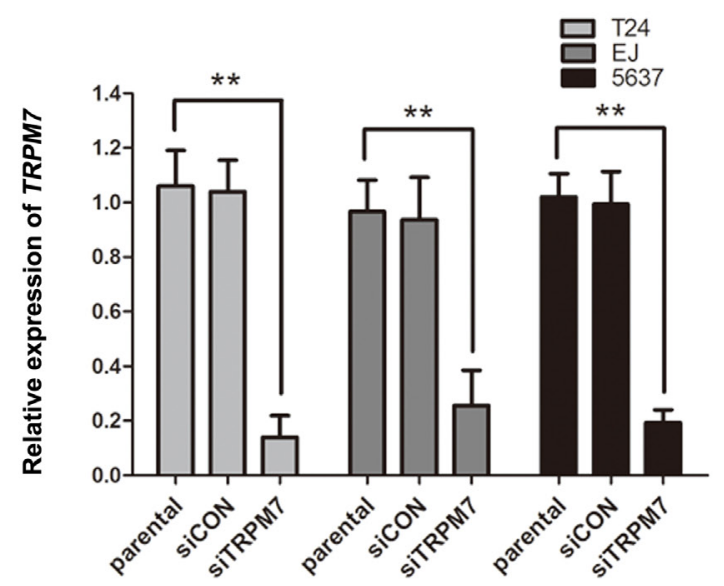

C
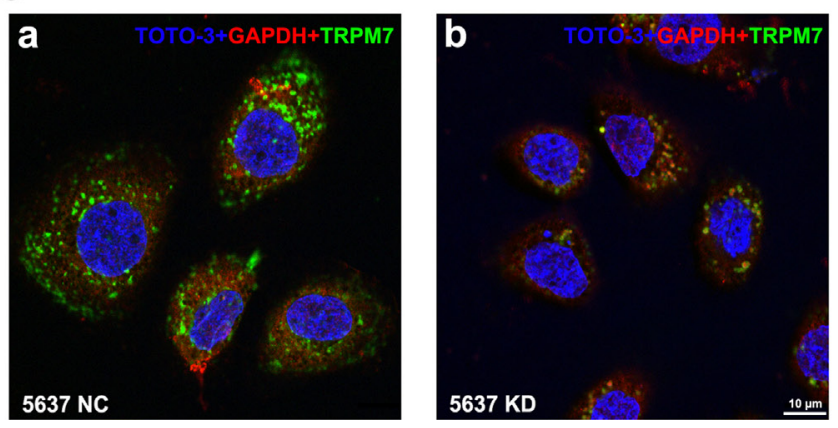

have analyzed the alterations of proteins involved in the apoptosis by Western blot (Figure 6C-6D), exhibiting upregulation of the apoptosis inducer BAX [43, 44] and downregulation of the apoptosis inhibitor BCL2 $[45,46]$ in the siTRPM7-treated BCa cells. Furthermore, pro-
D

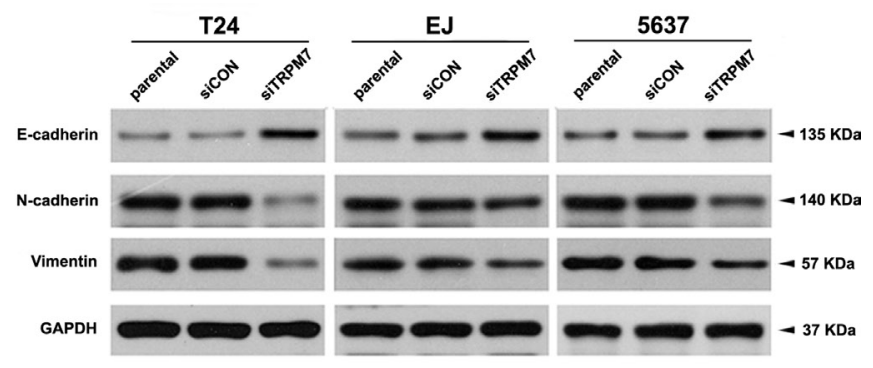

E


$\mathbf{F}$
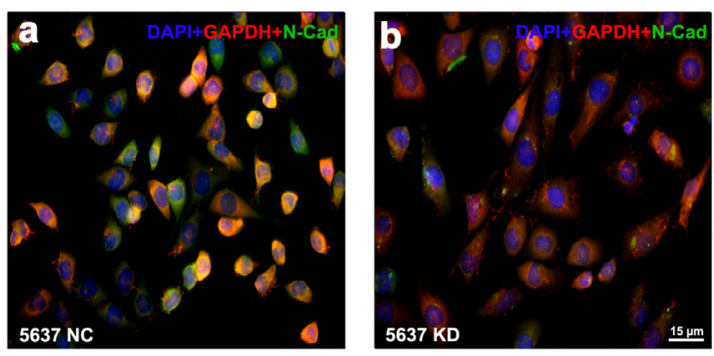

G

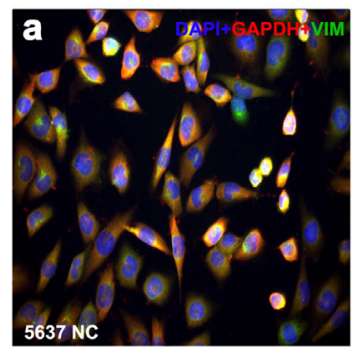

Figure 3: Knockdown of TRPM7 reversed EMT status and alleviated malignancy in BCa cells. (A-C) Efficiency of $T R P M 7$ knockdown by siRNA treatment in distinct BCa cells (T24, EJ, 5637) was verified by Western blot, qRT-PCR and double immunofluorescence staining analysis. (A) Western blot analysis revealed a strongly decreased protein abundance of TRPM7 by the siTRPM7 treatment, comparing with parental and siCON treatment. GAPDH was used as a loading control (cell types, treatment of siRNA and protein masses were indicated). (B) The relative gene expression of TRPM7 after $\operatorname{RiRNA}$ treatment was analyzed by qRT-PCR, indicating a significantly downregulation of TRPM7 at gene expression level in the three BCa cells. Values shown were mean $\pm \mathrm{SD}$ of triplicate measurements and repeated three times with similar results. Statistical significance was calculated using ANOVA. ${ }^{*} p<0.01$. (C) Representative double immunofluorescence staining of TRPM7 (green) and GAPDH (red) in the 5637 cells after siTRPM7 treatment (KD) (b), comparing with siCON treatment (NC) (a). Nuclears were stained by TOTO-3 (blue). The images were photographed by confocal microscopy. The scale bar for $\mathrm{C}(\mathrm{a}-\mathrm{b})$ is $10 \mu \mathrm{m}$. The effect on EMT markers (E-cadherin, N-cadherin and Vimentin) in the BCa cells by TRPM7 deficiency was investigated by Western blot and double immunofluorescence staining analysis. (D) Protein abundance of E-cadherin was increased by the siTRPM7 treatment in the three cell lines, in contrast, a reduce of N-cadherin and Vimentin was noted by the Western blot analysis. GAPDH abundance was used as a control. Cell types, treatment of siRNA and protein masses were indicated. (E-G) Representative double immunofluorescence staining for E-cadherin (E), N-cadherin (F) and Vimentin (G) (green) in the 5637 cells after siTRPM7 treatment (KD) (b) compared with siCON treatment (NC) (a). Nuclears were stained by DAPI (blue). The images were photographed by fluorescence microscopy. The scale bars for E-G are $15 \mu \mathrm{m}$. 



Figure 4: TRPM7 deficiency inhibited BCa cells migration and invasion through PI3K/AKT pathway. (A) Cell migration and invasion were evaluated by transwell assay for the parental, siCON- and siTRPM7-treated BCa cells by the transwell chamber system. Migrative and invasive cells were fixed and stained with crystal violet. Scale bar is $100 \mu \mathrm{m}$. The relative cell number of migration (B) and invasion $(\mathbf{C})$ in each cells was statistically analyzed. Cell types and treatment of siRNA were indicated. (D) Migration of parental, siCONand SiTRPM7-treated BCa cells was determined at 0,12 and $24 \mathrm{~h}$ by wound healing assay and the gap closure was statistically analyzed (E). All values for statistical analysis shown were mean \pm SD of triplicate measurements and repeated three times with similar results. Statistical significance was calculated using ANOVA. ${ }^{*} p<0.05,{ }^{* *} p<0.01$. (F) Western blot analysis for protein abundance of phosphorylated and total PI3K, AKT, FAK, as well as MMP2/9 in parental, siCON- and siTRPM7-treated BCa cells. GAPDH was used as a loading control (cell types, treatment of $s i R N A$ and protein masses were indicated). 
EJ
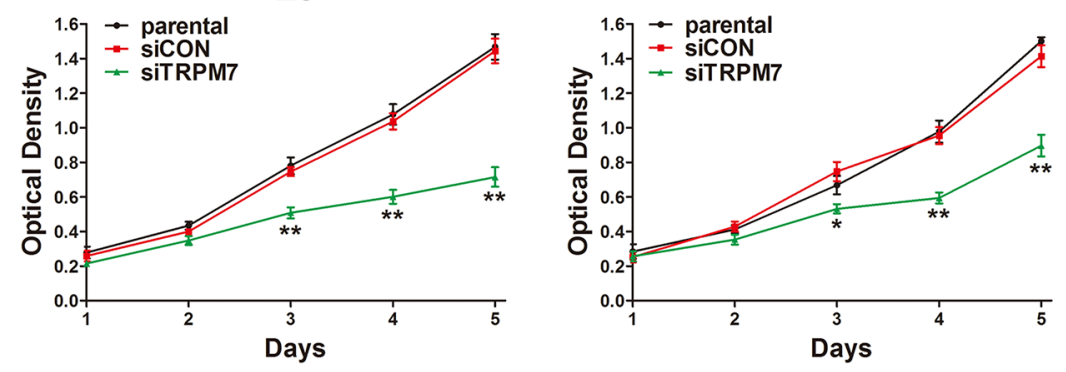

B
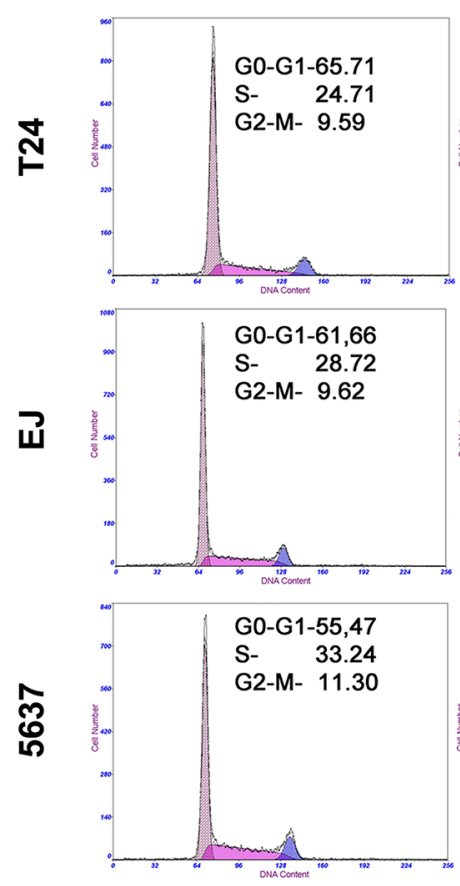

siCON
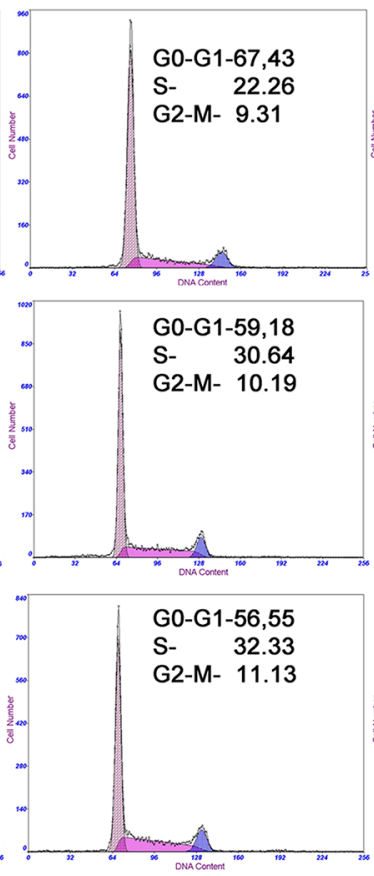

siTRPM7
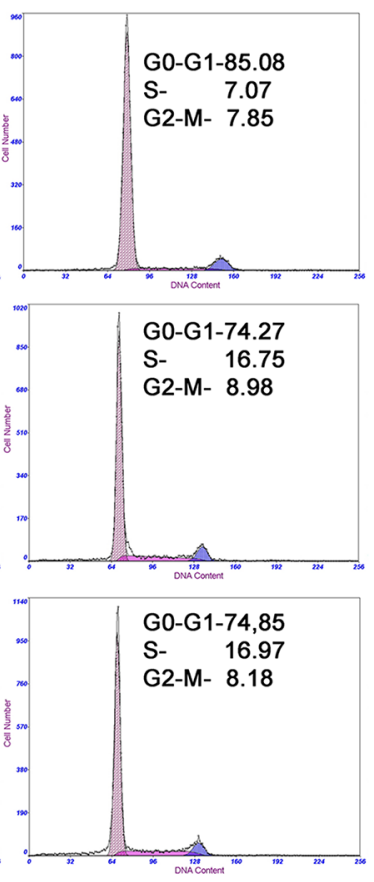

T24



EJ

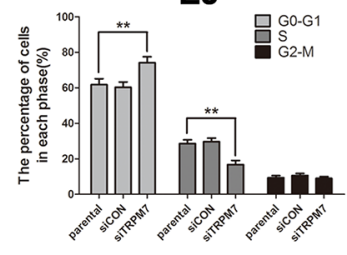

5637

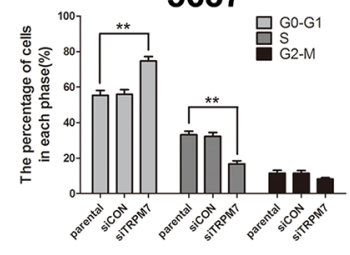

C

T24

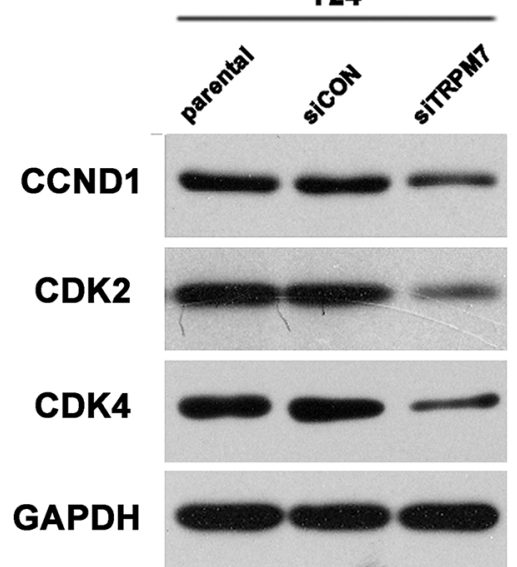

EJ

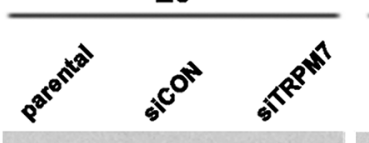

5637
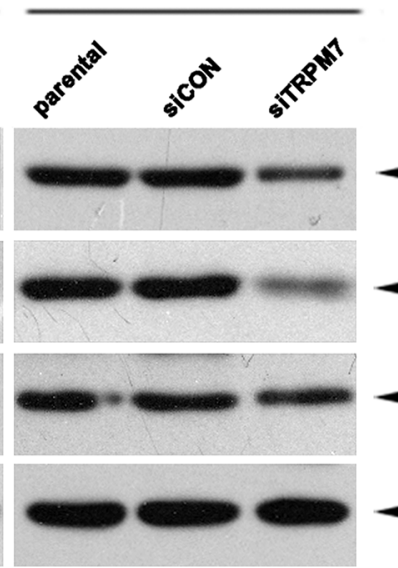

$36 \mathrm{KDa}$

33 KDa

$30 \mathrm{KDa}$

$37 \mathrm{KDa}$

Figure 5: Downregulation of TRPM7 repressed cell proliferation by triggering cell cycle arrest at G0/G1 phase in the BCa cells. (A) Viability of cells transfected with siTRPM7 from day 1 until day 5 was analyzed by CCK-8 assay, comparing with siCON and parental cells. (B) Flow cytometry analysis for the BCa cells treated with siTRPM7 for $48 \mathrm{~h}$ compared with siCON and parental cells. Percentages (\%) of cell populations at different stages of cell cycles were listed within the panels. All histograms revealed the percentage (\%) of cell populations from three independent experiments. Cell types and treatment of siRNA were indicated. ${ }^{*} p<0.05,{ }^{* *} p<0.01$. (C) Downregulation of protein abundance involved in the cell cyle regulation (CDK2, CDK4 and CCND1, also written as Cyclin D1) in the BCa lacking TRPM7 was revealed by Western blot analysis. GAPDH abundance was used as a control. Cell types, treatment of siRNA and protein masses were indicated. 
caspase 3, a downstream protein of BCL2 and BAX in the apoptotic cascade [47], was decreased, and its active form cleaved-caspase 3 was increased (Figure 6C). Moreover, we have found that Cytochrome $\mathrm{C}$ was also upregulated, suggesting that TRPM7 deficiency could trigger BCa cell apoptosis through a mitochondrial-dependent manner [48] (Figure 6C). Another key family, the MAPK including ERK1/2, JNK and p38, which are involved in the development and apoptosis regulation of tumor cells, was also altered in the siTRPM7-treated BCa cells (Figure 6D). TRPM7 deficiency strongly induced phosphorylated ERK1/2 (p-ERK1/2) in the BCa cells, with only a mild impact on $\mathrm{p}-\mathrm{JNK}$ and $\mathrm{p}-\mathrm{p} 38$.

A
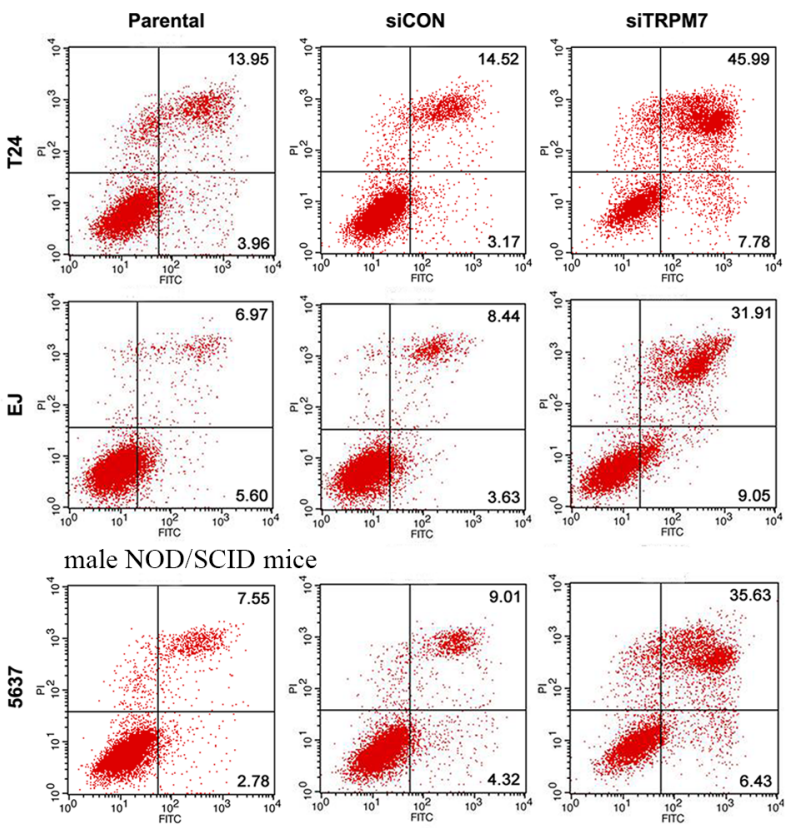

C



\section{Downregulation of TRPM7 induced BCa cell apoptosis through activation of ERK1/2}

We have pre-treated the BCa cells using U0126 to repress the activity of ERK1/2 and transfected with siTRPM7 and controls, revealing a significant recovery of cell growth delay triggered by TRPM7 deficiency in all the three $\mathrm{BCa}$ cells indicated by the CCK-8 assay (Figure 7A). Importantly, flow cytometry analysis exhibited that deactivation of ERK1/2 through pre-treatment with the U0126 (Figure 7B), could reverse TRPM7 deficiency induced apoptosis (statistically analyzed in Figure 7C), as demonstrated by reduced p-ERK1/2 and reversed BAX/

B

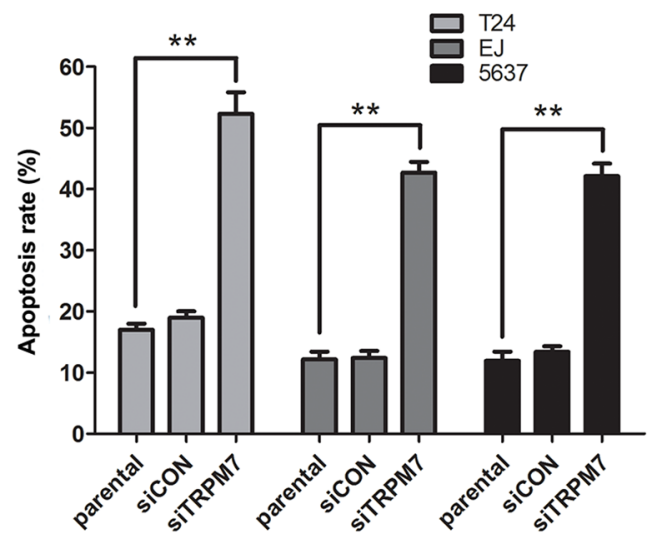

D

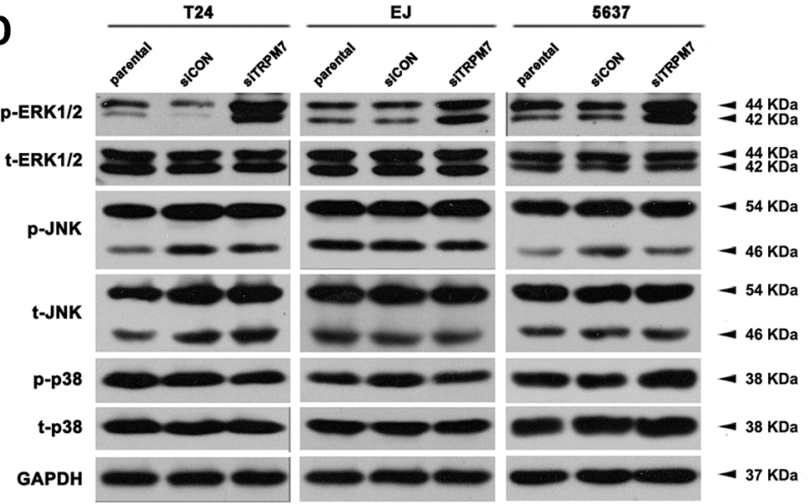

Figure 6: TRPM7 deficiency induced BCa cell apoptosis via ERK1/2 pathway. (A) Representative flow cytometry analysis of apoptosis stained with Annexin V and PI in parental, siCON- and siTRPM7-transfected BCa cells. (B) Statistical analysis of apoptotic rate $(\%)$ in the three BCa cell lines after the $\operatorname{siRNA}$ treatment. Cell types and treatment of $s i R N A$ were indicated. The values shown were mean $\pm \mathrm{SD}$ of triplicate measurements and repeated three times with similar results. Statistical significance was calculated using ANOVA. ${ }^{*} p<0.01$. (C) Western blot analysis for proteins involvement in mitochondrial dependent apoptotic pathway, such as BAX, BCL2, Cytochrome $\mathrm{C}$ and related proteins pro-caspase 3 and cleaved-caspase 3. (D) Proteins in the MAPK family were affected indicated by Western blot analysis. Phosphorylated and total ERK1/2, JNK and p38 at protein level was analyzed, suggesting a dominated activation of ERK1/2 in the MAPK family by the siTRPM7. GAPDH abundance was used as a control. Cell types, treatment of siRNA and protein masses were indicated. 
BCL2 ratio, as well as decreased Cytochrome $\mathrm{C}$ and cleaved-caspase 3 using Western blot analysis (Figure 7D).

\section{Reduction of either TRPM7 protein activity by carvacrol or TRPM7 gene transcription by lentiviral-shRNA could inhibit bladder cancer growth in vivo}

To further analyze the effects of TRPM7 activity in $\mathrm{BCa}$ tumorigenesis in vivo, a NOD/SCID mouse model transplanted with T24 cells was established (Figure 8A-8B). Two weeks after the transplantation, carvarcrol was intraperitoneally injected in the mice to inhibit the activity of TRPM7 (Figure 8A-8B, b). In contrast, other mice transplanted with $\mathrm{T} 24$ were injected by saline as control (Figure 8A-8B, a). The difference of tumor size for the carvacrol treated mice and the control mice was statistically analyzed in Figure 8C, suggesting a reduced tumor growth by the deactivation of TRPM7 protein in vivo. In addition, we also transplanted the T24 cells infected with lentiviral-TRPM7-shRNA (T24 LV-M7sh) to observe the tumor growth under downregulation of TRPM7 at transcriptional level (Figure 8D-8E). We noticed significantly decreased tumor size (Figure $8 \mathrm{~F}$ ) and weight (Figure $8 \mathrm{G}$ ) triggered by TRPM7 deficiency comparing with the control group (T24 LV-NC).

\section{Overexpression of TRPM7 induced BCa cell proliferation and motility}

BCa cells (T24 and EJ) were transfected with pcDNA5/FRT/TO/HA-TRPM7 vector to overexpress TRPM7 (Supplementary Figure S3A), which could trigger significantly increased cell proliferation revealed by CCK- 8 assay (Supplementary Figure S3B) and clonogenic survival assay (Supplementary Figure S3C). Induction of T24 and EJ cell migration rates was suggested by transwell migration assay, confirmed by the statistically analysis (Supplementary Figure S3D).

\section{DISCUSSION}

The TRPM family, an essential family of proteins exhibited distinct functions on tumorigenesis [49, 50]. Our group has reported that the TRPM family could regulate cell cycle and growth in human osteosarcoma and prostate cancer cells $[32,51]$. The present study aims to investigate
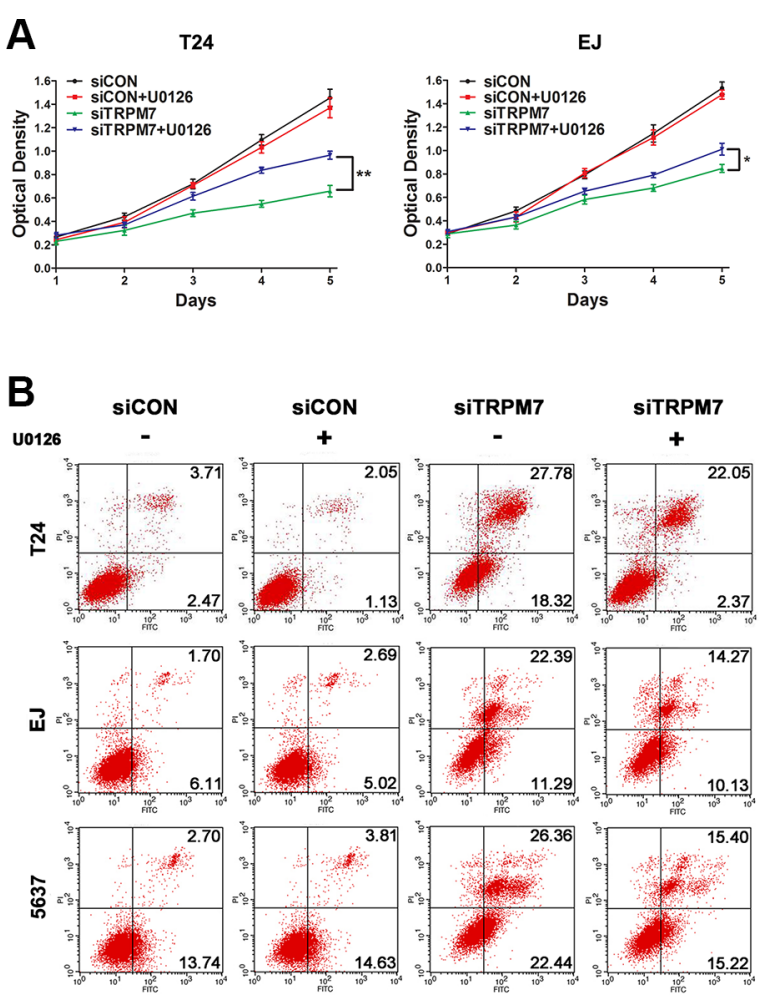
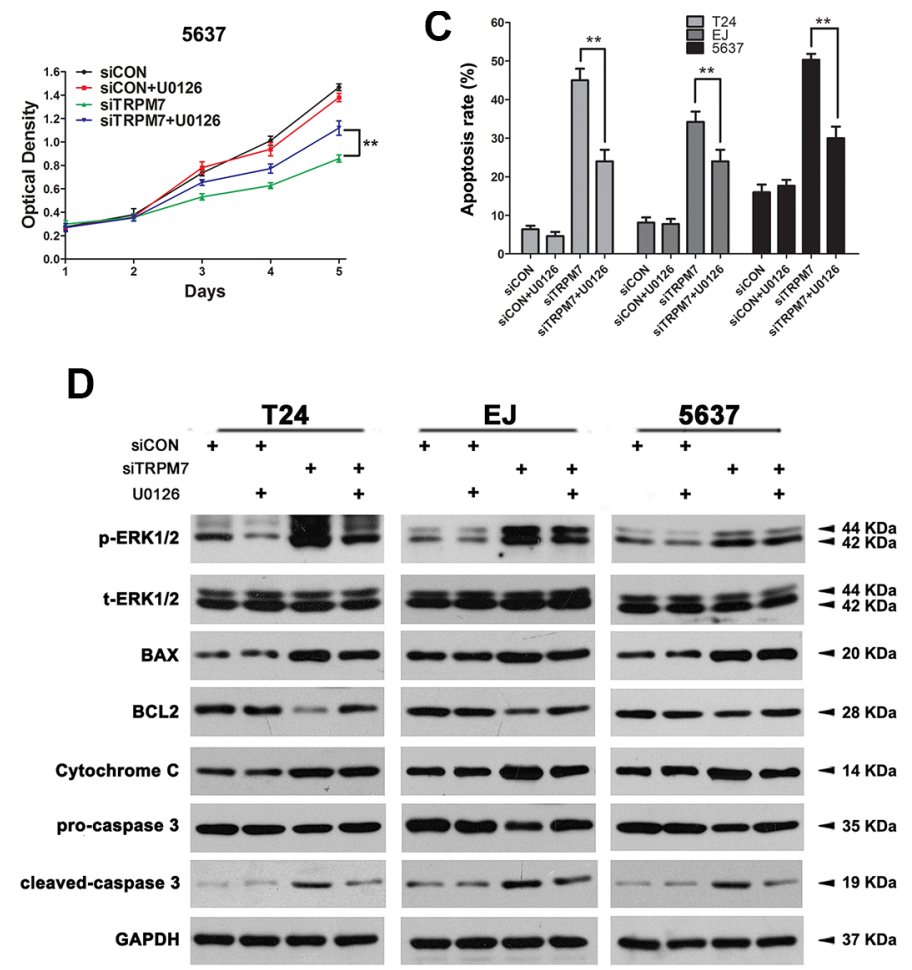

Figure 7: Recovering siTRPM7-induced BCa cell apoptosis by U0126 to deactivate ERK1/2. (A) T24, EJ, 5637 cells were pre-treated by U0126 at $10 \mathrm{mM}$ for $2 \mathrm{~h}$ and treated by SiTRPM7 for $48 \mathrm{~h}$, comparing with siCON and parental cells. Proliferation of the BCa cells were analyzed by CCK-8 assay. Cell types and treatment of $s i R N A$ were indicated. ${ }^{*} p<0.05,{ }^{*} p<0.01$. (B) Apoptotic cells staining with Annexin V and PI were revealed by flow cytometry analysis and the apoptotic rates were statistically analyzed $(\mathbf{C})$. Values of statistical data shown were mean \pm SD of triplicate measurements and repeated three times with similar results. Statistical significance was calculated using ANOVA. ${ }^{*} p<0.05,{ }^{*} p<0.01$. (D) Western blot analysis for phosphorylated and total ERK1/2 as well as mitochondrial dependent apoptotic pathway proteins (BAX, BCL2, Cytochrome C, pro-caspase 3 and cleaved-caspase 3). GAPDH abundance was used as a control. Cell types, treatment of $s i R N A$ and protein masses were indicated. 
A

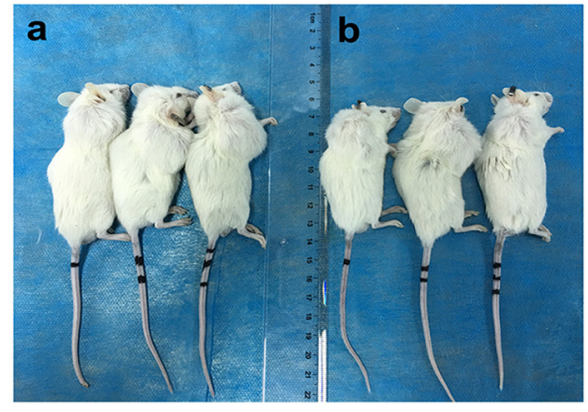

B

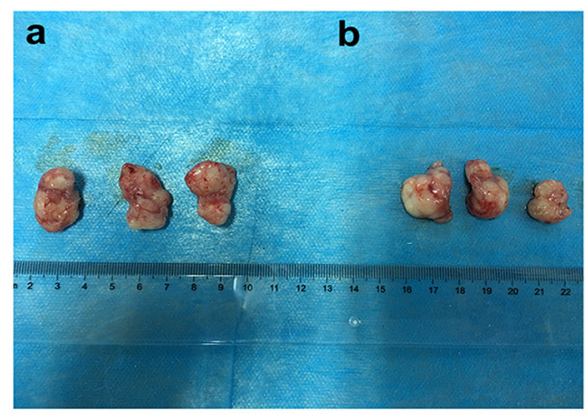

\section{C}

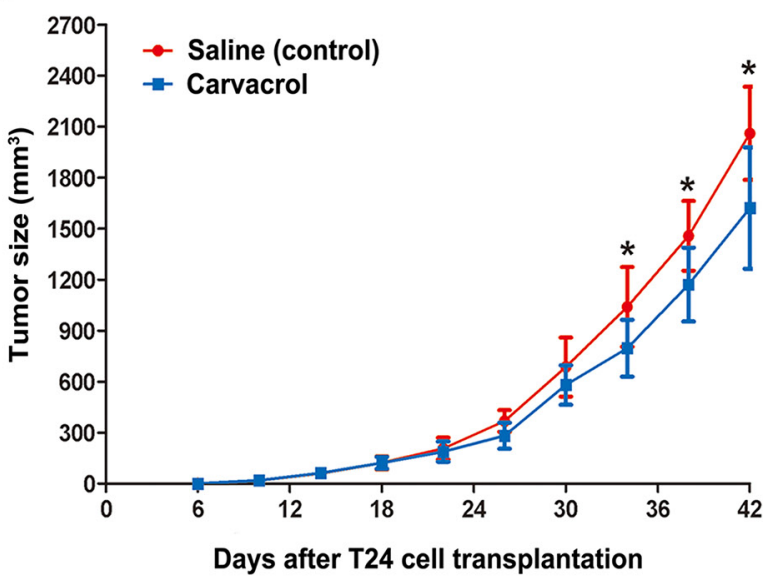

F


E



G



Figure 8: Deactivation of TRPM7 by carvacrol and decreased TRPM7 by lentiviral-shRNA suppressed bladder cancer growth in vivo. (A) Nude mice were subcutaneously transplanted with T24 cell for 14 days, and continueouslly intraperitoneally injected by carvacrol for 28 days (b) compared with injection by saline (a) as a control. (B) Dissected tumor from the nude mice injected by carvacrol (b) and saline (a). (C) Statistical analysis of tumor size $\left(\mathrm{mm}^{3}\right)$ measured by a caliper and calculated using $t$-test, ${ }^{*} p<0.05$. Days after T24 cell transplantation, tumor size and saline / carvacrol injection were indicated. (D) Nude mice were subcutaneously transplanted with T24 cell infected by lentiviral-TRPM7-shRNA (T24 LV-M7sh) for 42 days (b) compared with lentiviral-control-shRNA (T24 LV-NC) (a). (E) Dissected tumor from the nude mice injected by lentiviral-TRPM7-shRNA (T24 LV-M7sh) (b) and lentiviral-control-shRNA (T24 $L V$-NC) (a). Statistical analysis of tumor size $(\mathbf{F})$ and tumor weight $(\mathbf{G})$, calculated using $t$-test, ${ }^{*} p<0.05, * * p<0.01$. Days after T24 cell transplantation, tumor size and types of lentiviral-shRNA infection were indicated. 
the effect and mechanism of TRPM7, an important TRPM family member involved in $\mathrm{Ca}^{2+}$-permeable channel, on human bladder cancer, which remains largely unknown yet. Microarray analysis using human bladder cancer tissues compared with normal bladder epithelium tissues has suggested a close correlation between calcium signaling pathway and bladder cancer via MAPK signaling pathway, confirmed by overrepresentation using microarray raw data and DAVID database. We analyzed gene expression and protein abundance of TRPM7 in BCa tissues, observing a strong upregulation of TRPM7 at the gene expression and protein level by double immunofluorescence staining analysis, co-localized with OCT-4, a potential marker for $\mathrm{BCa}$ cells $[52,53]$. Moreover, we noticed the upregulation of TRPM7 may be correlated with the EMT markers in the $\mathrm{BCa}$ tissue, which could reveal the malignancy of tumor $[54,55]$.

We have selected three typical $\mathrm{BCa}$ cell lines with distinguished malignancy, T24, EJ and 5637, to generate the $\mathrm{BCa}$ cell model with TRPM7 deficiency using siRNA transfection. Indeed, we confirmed that knockdown of TRPM7 in the three BCa cell lines at gene expression and protein levels. Moreover, downregulation of TRPM7 resulted in a reversed status for the EMT markers, suggesting deficiency of TRPM7 could alleviate malignancy of BCa. Furthermore, our results revealed a significant increase of ROS status and protein abundance involved in the ROS metabolism in the BCa cells with downregulated TRPM7, suggesting a correlation between TRPM7 and ROS in BCa cells.

Knockdown of TRPM7 could reverse EMT markers in the three BCa cells, and we also observed that TRPM7 deficiency could also inhibit migration and invasion of $\mathrm{BCa}$ cells, as EMT has been reported to play a critical role in cancer cell migration and invasion [56]. To confirm the effect triggered by siTRPM7 treatment, we have established a BCa cell model with TRPM7-overexpression and noticed the migration rate was significantly increased. Moreover, treatment of siTRPM7 could also reduce MMP2/9 and phosphorylated FAK, PI3K, AKT in the BCa cells. Recent studies suggested FAK is a participant in focal adhesion dynamics between cells, playing a key role in cell motility [57] and MMPs could degrade the extracellular matrix and promote cancer cells to metastasize [58, 59]. Another publications reported that $\mathrm{PI} 3 \mathrm{~K} / \mathrm{AKT}$ is a key signaling pathway $[60,61]$, which was deactivated by the TRPM7 deficiency in our study as well, suggesting that inhibited BCa cell motility triggered by TRPM7 knockdown could be via the PI3K/AKT signaling pathway.

A major effect of TRPM7 was to induce delayed cell proliferation, cycle arrest at G0/G1 phase and apoptosis in the BCa cells with TRPM7 deficiency. Proteins involved in cell cycle regulation, CCND1 and CDK2/4, were all reduced after the siTRPM7 treatment. Moreover, proteins involved in apoptosis were strongly altered, especially imbalance of the BAX/BCL2 ratio, which is involved in mitochondrial-dependent apoptosis [62, 63], and related proteins including cleaved-caspase $3[64,65]$ and Cytochrome $\mathrm{C}[66,67]$, suggesting that TRPM7 deficiency could trigger a mitochondrial-mediated apoptosis. Importantly, as suggested by our microarray analysis, MAPK signaling pathway, a central regulator in the pathway network, could be altered by the affected calcium signaling pathway due to TRPM7 knockdown. Western blot analysis indicated ERK1/2, a member of MAPK family, was remarkably increased in the phosphorylated form, suggesting knockdown of TRPM7 might induce a mitochondrial dependent apoptosis via ERK1/2, which could be activated by phosphorylation on specific sites and promote either intrinsic or extrinsic apoptotic pathways by induction of mitochondrial Cytochrome $\mathrm{C}$ release or caspase- 8 activation, permanent cell cycle arrest or autophagic vacuolization [68].

Therefore, we deactivated ERK1/2 by pre-treatment of U0126 in the three BCa cells and noticed a decrease of the p-ERK1/2 at protein level. Furthermore, the delayed cell growth caused by siTRPM7 was reversed significantly, and the apoptotic cell rates were significantly reduced by ERK1/2 inhibition, as well as the proteins involved in the apoptosis pathway were recovered to the level of the control group. Importantly, we have established a T24transplanted NOD/SCID mouse model with carvacrol [69] and lentiviral-shRNA treatment respectively, observing a significant delayed tumor growth by both reduction of TRPM7 protein activity and TRPM7 gene transcription. Therefore, our results in vitro and in vivo have revealed that the downregulation of TRPM7 could reduce the $\mathrm{BCa}$ cell proliferation, trigger cell cycle arrest and apoptosis. In conclusion, downregulated TRPM7 could reduce the activity of bladder cancer cells and induce cell apoptosis via ERK1/2 pathway.

\section{MATERIALS AND METHODS}

\section{Ethical statement for human bladder tissue samples}

Three stage II bladder cancer tissue samples and three normal bladder tissue samples were collected from male patients (ages $62 \pm 1.581$ ) after surgery by radical resection and male donors (ages $37 \pm 2.327$ ) undergoing transplant by accidental death, at Zhongnan Hospital of Wuhan University, Wuhan, China. Informed consent was obtained from all subjects to collect the samples from the operating room and to store them in liquid nitrogen for total RNA isolation, as well as to fix the samples in $4 \%$ Paraformaldehyde (PFA) for immunofluorescence staining analysis. The study was approved by the Ethics Committee at Zhongnan Hospital of Wuhan University (approval number: 2015029, Supplementary Information S1) and the sample collection as well as treatment were carried out in accordance with the approved guidelines. 


\section{Ethical statement for NOD/SCID mice}

Investigation has been conducted in accordance with the ethical standards and according to the Declaration of Helsinki and according to national and international guidelines and has been approved by the author's institutional review board. Male NOD/SCID mice in this study were purchased from Beijing HFK Bioscience Co., Ltd. in Beijing, China (http://www.hfkbio.com/en/).

\section{Human bladder cancer cell lines}

Human bladder cancer cell lines EJ cells (carcinoma, Cat. \#CL-0274) and BIU-87 (Cat. \#CL-0035) were purchased from the Procell Co., Ltd. in Wuhan, China. The T24 (transitional cell carcinoma, Cat. \#SCSP-536), 5637 (grade II carcinoma, Cat. \#TCHu1), UM-UC-3 (Cat. \#TCHu217), RT-4 (Cat. \#TCHu226) and SV-HUC-1 (Cat. \#TCHu169) were kindly provided by the Stem Cell Bank, Chinese Academy of Sciences in Shanghai, China. Identification of the $\mathrm{BCa}$ cell lines was at the China Centre for Type Culture Collection in Wuhan, China. The EJ, BIU-87, T24, 5637 and SV-HUC-1 cells were cultured in RPMI-1640 medium (Gibco, China), UM-UC-3 cells were cultured in DMEM medium (Gibco, China) and RT-4 cells were cultured in McCoy's 5A Medium (Gibco, China) containing $1 \%$ penicillin G sodium/streptomycin sulphate and $10 \%$ fetal bovine serum (FBS) (Gibco, Australia) in a humidified atmosphere consisting of $95 \%$ air and $5 \%$ $\mathrm{CO}_{2}$ at $37^{\circ} \mathrm{C}$.

\section{RNA expression analyses}

\section{Total RNA isolation from bladder tissues and BCa cells}

Total RNA was isolated from bladder tissues and distinct $\mathrm{BCa}$ cells using the Qiagen RNeasy Mini Kit (Cat \#74101), combined with QIAshredder from Qiagen (Cat \#79654) using a centrifuge (Eppendorf, Cat \#5424) to increase the quantity and quality of isolated total RNA, according to the manufacturer's protocol. Each RNA sample was digested by DNase I (RNase-Free DNase Set, Qiagen, Cat \#79254) to remove possible contamination of genomic DNA. The quantity of isolated RNA was measured by a NanoDrop ${ }^{\circledR}$ ND-1000 UV-Vis spectrophotometer (Thermo Scientific, USA).

\section{Microarray analysis of mRNA isolated from human bladder tissues}

Our group has established a microarray analysis using mRNA isolated from the three stage II bladder cancer tissues and the three normal bladder tissues, as described by Wang et al. in 2016 [2]. Briefly, according to the standard Affymetrix protocol, $250 \mathrm{ng}$ total RNA of each sample was prepared to biotinylated cDNA by Ambion $^{\circledR}$ WT Expression Kit. On GeneChip Human Transcriptome Array 2.0, $5.5 \mu \mathrm{g}$ of cDNA were hybridized for $16 \mathrm{~h}$ at $45^{\circ} \mathrm{C}$, continuously washed and stained in the Affymetrix Fluidics Station 450, scanned by using Affymetrix ${ }^{\circledR}$ GeneChip Command Console (AGCC) installed in GeneChip ${ }^{\circledR}$ Scanner 3000 (7G). Data analysis was with a Robust Multichip Analysis (RMA) algorithm using Affymetrix default analysis settings and global scaling as normalization method. By Gene ontology (GO) and pathway-Relation-Network (Path-net) analysis tools based on Kyoto Encyclopedia of Genes and Genomes (KEGG) Pathway Database using Gene Cloud of Biotechnology Information (GCBI Plateform, Shanghai, China) [70], genes and pathways correlated with bladder cancer were generated. The resulting gene list was subjected to the Database for Annotation, Visualization and Integrated Discovery (DAVID) [71] as well for annotation and overrepresentation analysis of the genes involved in calcium signaling pathway (Supplementary Figure S2). The microarray data was submitted to the Gene Expression Omnibus (GEO) database with accession number GSE76211. All data are MIAME compliant.

\section{Reverse transcription and quantitative real time PCR (qRT-PCR)}

$1 \mu \mathrm{g}$ of total RNA isolated from bladder tissues or BCa cells was mixed with oligo (dT) $12-18$ primers to synthesize first-strand cDNA by using RevertAid First Strand cDNA Synthesis Kit (Thermo Scientific, China). $1 \mu \mathrm{g}$ cDNA were used for each reaction of the polymerase chain reactions (PCR) in a final volume of $20 \mu$ l. All primers conducted with the SYBR Premix Ex Taq II (Takara Bio, China) were tested for optimal annealing temperatures and PCR conditions were optimized with gradient PCRs on a Bio-Rad iCycler (Cat. \#CFX96). Primer sequences and annealing temperatures are summarized in Table 1. Values were normalized for amplified $\beta$-actin alleles. Relative gene abundance $=2^{-\Delta \Delta c t}$, $\Delta \mathrm{ct}=\mathrm{ct}_{\text {target gene }}-\mathrm{ct}_{\beta \text {-actin }}$, for BCa cells $\Delta \Delta \mathrm{ct}=\Delta \mathrm{ct}_{\text {siRNA-treated }}$ - $\Delta \mathrm{ct}_{\text {siRNA-untreated }}$, for bladder tissues $\Delta \Delta \mathrm{ct}=\Delta \mathrm{ct}_{\mathrm{BCa}}$ tissues $\Delta \mathrm{ct}_{\text {normal bladder tissues }}(\mathrm{ct}=$ threshold cycle $)$.

\section{Cell culture experiments}

\section{Knockdown and overexpression of TRPM7 in the BCa cells}

TRPM7-target specific small interfering RNA (siRNA) and lentiviral small hairpin RNA (LV-shRNA) were synthesized by Genepharma Ltd. in Suzhou, China. Distinct BCa cells (T24, EJ and 5637) were transfected with TRPM7-SiRNA (siTRPM7) using lipofectamine 2000 (Invitrogen, USA), according to the 
Table 1: List of primers for qRT-PCR

\begin{tabular}{|c|c|c|c|c|c|}
\hline Gene & Symbol & $\begin{array}{l}\text { Forward primer } \\
\qquad\left(5^{\prime}-3^{\prime}\right)\end{array}$ & Reverse primer $\left(5^{\prime}-3^{\prime}\right)$ & $\begin{array}{c}\text { Annealing } \\
\text { temperature } \\
\left({ }^{\circ} \mathrm{C}\right)\end{array}$ & $\begin{array}{l}\text { Length } \\
\text { (bp) }\end{array}$ \\
\hline $\begin{array}{l}\text { Transient receptor } \\
\text { potential melastatin } 7\end{array}$ & TRPM7 & $\begin{array}{l}5^{\prime} \text { - TGGATGATGGC } \\
\text { ACTGTTGGAA -3' }\end{array}$ & $\begin{array}{l}5^{\prime}-\text { CATTTGGCCC } \\
\text { ACCCTCAAATATAA -3' }\end{array}$ & 56 & 144 \\
\hline Actin, beta & $A C T B$ & $\begin{array}{l}5^{\prime}-\text { AGAGCTACGA } \\
\text { GCTGCCTGAC -3' }\end{array}$ & $\begin{array}{l}5^{\prime} \text { - AGCACTGTGTT } \\
\text { GGCGTACAG -3' }\end{array}$ & 56 & 184 \\
\hline $\begin{array}{l}\text { calcium/calmodulin } \\
\text { dependent protein } \\
\text { kinase II beta }\end{array}$ & CAMK II B & $\begin{array}{l}\text { 5'- GCACACCA } \\
\text { GGCTACCTGTC - } 3^{\prime}\end{array}$ & $\begin{array}{l}\text { 5'- GGACGGGAAG } \\
\text { TCATAGGCA -3' }\end{array}$ & 56 & 179 \\
\hline calmodulin 1 & CALM1 & $\begin{array}{l}5^{\prime} \text { - TTGACTTCCCC } \\
\text { GAATTTTTGACT -3' }\end{array}$ & $\begin{array}{l}5^{\prime} \text { - GGAATGCCTCA } \\
\text { CGGATTTCTT -3' }\end{array}$ & 56 & 81 \\
\hline calmodulin 3 & CALM3 & $\begin{array}{l}5^{\prime}-\text { GACCATTGAC } \\
\text { TTCCCGGAGTT -3' }\end{array}$ & $\begin{array}{l}\text { 5'- GATGTAGCCATT } \\
\text { CCCATCCTTG -3' }\end{array}$ & 56 & 118 \\
\hline $\begin{array}{l}\text { protein phosphatase } 3 \\
\text { catalytic subunit alpha }\end{array}$ & PPP3CA & $\begin{array}{l}\text { 5'- CCAAGTCACC } \\
\text { GGCTTACAG -3' }\end{array}$ & $\begin{array}{l}\text { 5'- CCTCCTTCATAA } \\
\text { GATGCGCCTT -3' }\end{array}$ & 56 & 88 \\
\hline $\begin{array}{l}\text { protein phosphatase } 3 \\
\text { catalytic subunit beta }\end{array}$ & PРP3CB & $\begin{array}{l}\text { 5'- CCCCAACACATC } \\
\text { GCTTGACAT-3' }\end{array}$ & $\begin{array}{l}\text { 5'- GGCAGCACCCT } \\
\text { CATTGATAATTC -3' }\end{array}$ & 56 & 140 \\
\hline $\begin{array}{l}\text { protein phosphatase } 3 \\
\text { catalytic subunit gamma }\end{array}$ & PPP3CC & $\begin{array}{l}\text { 5'- ACCGCGTCATC } \\
\text { AAAGCTGT-3' }\end{array}$ & $\begin{array}{l}\text { 5'- CTTCCAGTCGT } \\
\text { CCTTCCTTTAC -3' }\end{array}$ & 56 & 125 \\
\hline
\end{tabular}

manufacturer's protocol. The sense sequence of TRPM7siRNA (siTRPM7) / TRPM7-shRNA (shTRPM7) was 5'-GUCUUGCCAUGAAAUACUCTT- ${ }^{\prime}$ ', and the sense sequence of control-siRNA ( $s i C O N)$ / control-shRNA $(\operatorname{shCON})$ was 5'-UUCUCCGAACGUGUCAGGUTT-3'. After transfection by SiTRPM7 for $48 \mathrm{~h}$, alterations of $T R P M 7$ at transcriptional and protein levels were evaluated by the qRT-PCR, Western blot and immunofluorescence staining analysis. The $\mathrm{BCa}$ cells infected by lentiviralTRPM7-shRNA (LV-M7sh) and lentiviral-control-shRNA $(L V-N C)$ were treated by $0.8 \mathrm{mg} / \mathrm{ml}$ puromycin (Sigma, USA) for 14 days to select the antibiotic-resistant cells xenotransplanted into NOD/SCID mice.

The plasmid of TRPM7-overexpression (pcDNA5/ FRT/TO/HA-TRPM7 vector) was a gift from Professor Loren W. Runnels at University of Medicine \& Dentistry of New Jersey, USA. The cell model of TRPM7-overexpression was established according to $\mathrm{Su}$ et al. [72] from the group of Professor Runnels. Briefly, the BCa cells (EJ and T24) were transfected by the pcDNA5/FRT/TO/HA-TRPM7 vector and induced by $1 \mathrm{mg} / \mathrm{ml}$ tetracyclines for $48 \mathrm{~h}$.

\section{Pre-treatment using MKK inhibitor for rescue experiments}

Before siRNA transfection, $\mathrm{BCa}$ cells were pretreated by MKK inhibitor U0126 (Sigma, USA) at $10 \mathrm{mM}$ for $2 \mathrm{~h}$ to deactivate ERK1/2 [13, 73, 74]. BCa cells in the untreated group were pre-incubated with appropriate amount of vehicle $(0.1 \%$ DMSO). Both groups were submitted for the RNA interference and alterations of cell viability and apoptosis were measured by CCK- 8 assay and flow cytometry analysis, respectively.

\section{Wound healing assay}

When the BCa cells grew to $95 \%$ confluence, a 200 $\mu \mathrm{l}$ pipette tip was used to scratch a wound to cell monolayer. After scratching, cells were washed with PBS several times to remove non-adherent debris, then $0.5 \%$ FBS medium was added to allow cells to move into the gap without the influence of serum. Four different equidistant points of the scratched area were photographically measured and imaged by an inverted phase contrast microscope (Leica, Cat. \#DMI 1) at $0 \mathrm{~h}, 12 \mathrm{~h}$ and $24 \mathrm{~h}$. Migration rate was calculated as the proportion of initial scratch distant of each sample using the mean distance between both borderlines that remain cell-free after cell migration.

\section{Transwell migration assay}

A 24-well plate transwell chamber system (Corning, USA) with $8.0 \mu \mathrm{m}$ pore size was used. Cells were suspended in $0.5 \%$ FBS medium at a density of $5 \times 10^{5}$ cell $/ \mathrm{ml}$ and $100 \mu \mathrm{l}$ cell suspension was seeded in the upper chamber insert without ligand, while the lower chamber was filled with $10 \%$ FBS medium. After $24 \mathrm{~h}$ incubation at $37^{\circ} \mathrm{C}$, cells on the upper insert were removed by cotton 
swabs, and cells that migrated to the lower side were fixed with 4\% PFA and stained with crystal violet. Then the chambers were placed under an inverted phase contrast microscope and 16 random areas were selected to observe and count the migrated cells.

\section{Transwell invasion assay}

In transwell invasion analysis, $40 \mu \mathrm{l}$ ECM gel solution (Sigma, USA) diluted to a concentration of $1 \mathrm{mg} / \mathrm{ml}$ was coated on the surface of the upper insert of Transwell chamber and placed in a $37^{\circ} \mathrm{C}$ incubator for overnight. BCa cells were then suspended in $0.5^{\circ} \mathrm{C}$ FBS medium at a density of $8 \times 10^{5} \mathrm{cell} / \mathrm{ml}$ and $100 \mu \mathrm{l}$ cell suspension was seeded in the upper chamber insert. After incubation $48 \mathrm{~h}$ at $37^{\circ} \mathrm{C}$, cells were fixed, stained and counted under an inverted phase contrast microscope.

\section{CCK-8 assay}

Cell Counting Kit-8 (Roche Biochemicals, Germany) was used for cell viability measurement. $100 \mu \mathrm{l}$ cell suspensions $\left(2 \times 10^{4}\right.$ cells per $\left.\mathrm{ml}\right)$ with $10 \%$ FBS medium was seeded to a 96 -well plate and incubated for 5 days at $37^{\circ} \mathrm{C}$. Then, $10 \mu \mathrm{CCK}-8$ reagent was added to each well at the indicated time and incubated for $4 \mathrm{~h}$ at $37^{\circ} \mathrm{C}$. Absorbance was measured at $450 \mathrm{~nm}$ by a Rayto-6000 system (Rayto, China).

\section{Clonogenic survival assay}

BCa cells were seeded in 6-well plates (1500 cells per well) and grew into colonies for approximately 15 days. Colonies were emerged and fixed by $4 \%$ PFA for $30 \mathrm{~min}$, staining with crystal violet, counted and defined as aggregates of 50 or more cells and photographed.

\section{Flow cytometry analysis for alterations of cell cycle and apoptosis}

For cell cycle analysis, $1 \times 10^{6}$ cells were harvested and fixed in $70 \%$ ice cold ethanol at $-20^{\circ} \mathrm{C}$ for overnight. After centrifugation, pellets were resuspended with PBS containing $50 \mu \mathrm{g} / \mathrm{ml}$ propidium iodide (Sigma-Aldrich, USA) and $0.1 \mathrm{mg} / \mathrm{ml} \mathrm{RNaseA}(20 \mu \mathrm{g} / \mathrm{ml}$ in PBS $)$ in the dark. After incubation at $37^{\circ} \mathrm{C}$ for $30 \mathrm{~min}$, the DNA content distribution was analyzed by flow cytometry analysis (Beckman, Cat. \#FC500). For apoptosis analysis, after transfection for 48 $\mathrm{h}$, cells were collected, washed with PBS, and stained with FITC Annexin V Apoptosis Detection Kit I (BD biosciences, USA) and analyzed by the flow cytometry analysis.

\section{ROS detection by staining with DCFH-DA}

The fluorescent probe 2',7'-Dichlorofluorescin diacetate (DCFH-DA) was used to evaluate intracellular ROS levels. BCa cells transfected with siTRPM7 and $s i C O N$ were used for this experiment. After transfection of cells and growth for $48 \mathrm{~h}, 10 \mu \mathrm{mol}$ of DCFH-DA (Sigma, USA) was added to $2 \mathrm{ml}$ medium, and incubated at $37^{\circ} \mathrm{C}$ for $30 \mathrm{~min}$. Thereafter, the cells were washed three times with PBS and submitted to flow cytometry analysis. For ROS staining, slides with the BCa cells were stained by DCFH-DA and incubated for $30 \mathrm{~min}$ at room temperature, then washed by PBS three times. Nuclei were counterstained with $1 \mu \mathrm{M}$ DAPI for $20 \mathrm{~min}$ at room temperature. Images were taken with a fluorescence microscope (Olympus, Cat. \#IX73).

\section{Protein analyses}

\section{Isolation of total protein from BCa cells and Western blot analysis}

The BCa cells (T24, EJ and 5637) were sonicated and lysed in RIPA buffer containing protease inhibitor and phosphatase inhibitor (Sigma-Aldrich, USA) on ice for $30 \mathrm{~min}$, then centrifuged at $12,000 \mathrm{~g}$ for $15 \mathrm{~min}$ to collect supernatant. By Bradford protein assay (Bio-Rad, Germany) the concentrations of protein were determined using Bovine serum albumin (BSA) as standard. The isolated total protein was resolved using 6-15\% SDSPAGE and transferred to PVDF membrane (Millipore, USA). Membranes were blocked by $5 \%$ non-fat milk and incubated with primary antibodies (Table 2 ) at $4{ }^{\circ} \mathrm{C}$ for overnight. After washing, the membranes were incubated with secondary antibody (listed in Table 3) at room temperature for $2 \mathrm{~h}$. Bands were visualized using an enhanced chemiluminescence (ECL) kit (Bio-rad, USA) and detected by Kodak Biomax MR films.

\section{Immunofluorescence staining for human bladder tissue samples}

Histological diagnosis of bladder tissues were examined by two experienced pathologists independently. All the samples were fixed by $4 \%$ PFA at $4^{\circ} \mathrm{C}$ overnight and embedded into paraffin (Paraplast, Sigma-Aldrich) using tissue processor (Thermo Fisher Scientific, Cat. \#STP 120). Paraffin sections $(4 \mu \mathrm{m})$ were cut with a rotation microtome (Thermo Fisher Scientific, Cat. \#HM325). The sections were serially incubated with indicated primary antibody (listed in Table 2) and Cy3-labeled or FITC- labeled secondary antibody (listed in Table 3) in humidified atmosphere. Nuclei were labeled with DAPI $(2 \mu \mathrm{g} / \mathrm{ml})$. Sections were analyzed by a fluorescence microscope (Olympus, Cat. \#IX73).

\section{Immunofluorescence analysis for BCa cells}

BCa cells were seeded on $12 \mathrm{~mm}$ coverslips, washed three times with ice cold PBS and fixed with 4\% PFA for 30 min. Cells were then treated with $0.1 \%$ Triton X-100 solution and blocked in normal goat serum for $30 \mathrm{~min}$ at room temperature. Afterwards, cells were incubated with the indicated primary antibody (Table 2) at the proper dilution 
Table 2: List of primary antibodies

\begin{tabular}{|c|c|c|c|c|}
\hline Antigens & $\begin{array}{l}\text { Species antibodies } \\
\text { raised in }\end{array}$ & $\begin{array}{l}\text { Dilution } \\
\text { (IF) }\end{array}$ & Dilution (WB) & Supplier \\
\hline Akt (pan), mouse & Rabbit, monoclonal & - & $1: 2,000$ & $\begin{array}{l}\text { Cell Signaling Technology, USA, } \\
\text { Cat. \#4691 }\end{array}$ \\
\hline Bax, human & Rabbit, monoclonal & - & $1: 2,000$ & $\begin{array}{l}\text { Cell Signaling Technology, USA, } \\
\text { Cat. } \# 5023\end{array}$ \\
\hline Bcl-2, human & Rabbit, monoclonal & - & $1: 2,000$ & $\begin{array}{l}\text { Cell Signaling Technology, USA, } \\
\text { Cat. \#2872 }\end{array}$ \\
\hline Caspase-3, human & Rabbit, monoclonal & - & $1: 2,000$ & $\begin{array}{l}\text { Cell Signaling Technology, USA, } \\
\text { Cat. \#9665 }\end{array}$ \\
\hline Cytochrome c, human & Rabbit, monoclonal & - & $1: 500$ & $\begin{array}{l}\text { Cell Signaling Technology, USA, } \\
\text { Cat. } \# 4280\end{array}$ \\
\hline CDK2, human & Rabbit, monoclonal & - & $1: 2,000$ & $\begin{array}{l}\text { Cell Signaling Technology, USA, } \\
\text { Cat. \#2546 }\end{array}$ \\
\hline CDK4, human & Rabbit, monoclonal & - & $1: 2,000$ & $\begin{array}{l}\text { Cell Signaling Technology, USA, } \\
\text { Cat. \#12790 }\end{array}$ \\
\hline Cleaved Caspase-3, human & Rabbit, monoclonal & - & $1: 500$ & $\begin{array}{l}\text { Cell Signaling Technology, USA, } \\
\text { Cat. \#9664 }\end{array}$ \\
\hline Cyclin D1, human & Rabbit, monoclonal & - & $1: 2,000$ & $\begin{array}{l}\text { Cell Signaling Technology, USA, } \\
\text { Cat. \#2978 }\end{array}$ \\
\hline E-cadherin, human & Rabbit, monoclonal & $1: 200$ & $1: 500$ & $\begin{array}{l}\text { Cell Signaling Technology, USA, } \\
\text { Cat. \#3195 }\end{array}$ \\
\hline FAK, human & Rabbit, monoclonal & - & $1: 1,000$ & $\begin{array}{l}\text { Cell Signaling Technology, USA, } \\
\text { Cat. \#13009 }\end{array}$ \\
\hline $\begin{array}{l}\text { Glyceraldehyde 3-phosphate } \\
\text { dehydrogenase (GAPDH), } \\
\text { human }\end{array}$ & Mouse, monoclonal & $1: 200$ & $1: 2,000$ & $\begin{array}{l}\text { Santa Cruz Biotechnology Inc., } \\
\text { USA, Cat. \#sc-365062 }\end{array}$ \\
\hline MMP-2, human & Rabbit, monoclonal & - & $1: 500$ & $\begin{array}{l}\text { Cell Signaling Technology, USA, } \\
\text { Cat. \#13132 }\end{array}$ \\
\hline MMP-9, human & Rabbit, monoclonal & - & $1: 1,000$ & $\begin{array}{l}\text { Cell Signaling Technology, USA, } \\
\text { Cat. \#13667 }\end{array}$ \\
\hline N-cadherin, human & Rabbit, monoclonal & $1: 200$ & $1: 1,000$ & $\begin{array}{l}\text { Cell Signaling Technology, USA, } \\
\text { Cat. \#13116 }\end{array}$ \\
\hline OCT-4, human & Rabbit, monoclonal & $1: 200$ & $1: 1,000$ & $\begin{array}{l}\text { Cell Signaling Technology, USA, } \\
\text { Cat. } \# 2750\end{array}$ \\
\hline OCT-4, human & Mouse, monoclonal & $1: 200$ & - & $\begin{array}{l}\text { Novus Biologicals, USA, Cat. } \\
\text { \#NB110-90606 }\end{array}$ \\
\hline p38 MAPK, human & Rabbit, monoclonal & - & $1: 2,000$ & $\begin{array}{l}\text { Cell Signaling Technology, USA, } \\
\text { Cat. \#8690 }\end{array}$ \\
\hline p44/42 MAPK (Erk1/2), rat & Rabbit, monoclonal & - & $1: 2,000$ & $\begin{array}{l}\text { Cell Signaling Technology, USA, } \\
\text { Cat. \#4695 }\end{array}$ \\
\hline $\begin{array}{l}\text { Phospho-Akt (Ser473), } \\
\text { human }\end{array}$ & Rabbit, monoclonal & - & $1: 1,000$ & $\begin{array}{l}\text { Cell Signaling Technology, USA, } \\
\text { Cat. } \# 4060\end{array}$ \\
\hline $\begin{array}{l}\text { Phospho-FAK (Tyr397), } \\
\text { human }\end{array}$ & Rabbit, monoclonal & - & $1: 1,000$ & $\begin{array}{l}\text { Cell Signaling Technology, USA, } \\
\text { Cat. \#8556 }\end{array}$ \\
\hline $\begin{array}{l}\text { Phospho-p38 (Thr180/ } \\
\text { Tyr182), human }\end{array}$ & Rabbit, monoclonal & - & $1: 1,000$ & $\begin{array}{l}\text { Cell Signaling Technology, USA, } \\
\text { Cat. \#4511 }\end{array}$ \\
\hline $\begin{array}{l}\text { Phospho-p44/42 MAPK } \\
\text { (Erk1/2) (Thr202/Tyr204), } \\
\text { human }\end{array}$ & Rabbit, monoclonal & - & $1: 1,000$ & $\begin{array}{l}\text { Cell Signaling Technology, USA, } \\
\text { Cat. } \# 4370\end{array}$ \\
\hline
\end{tabular}




\begin{tabular}{|l|l|c|c|l|}
\hline $\begin{array}{l}\text { Phospho-PI3 Kinase p85 } \\
\text { (Tyr458)/p55 (Tyr199), } \\
\text { mouse }\end{array}$ & Rabbit, monoclonal & - & $1: 1,000$ & $\begin{array}{l}\text { Cell Signaling Technology, USA, } \\
\text { Cat. \#4228 }\end{array}$ \\
\hline $\begin{array}{l}\text { Phospho-SAPK/JNK } \\
\text { (Thr183/Tyr185), human }\end{array}$ & Rabbit, monoclonal & - & $1: 1,000$ & $\begin{array}{l}\text { Cell Signaling Technology, USA, } \\
\text { Cat. \#4668 }\end{array}$ \\
\hline PI3 Kinase p85, human & Rabbit, monoclonal & - & $1: 1,000$ & $\begin{array}{l}\text { Cell Signaling Technology, USA, } \\
\text { Cat. \#4257 }\end{array}$ \\
\hline SAPK/JNK, human & Rabbit, monoclonal & - & $1: 2,000$ & $\begin{array}{l}\text { Cell Signaling Technology, USA, } \\
\text { Cat. \#9252 }\end{array}$ \\
\hline TRPM7, mouse & Mouse, monoclonal & $1: 100$ & $1: 500$ & Abcam, UK, Cat. \#ab85016 \\
\hline Vimentin, human & Rabbit, monoclonal & $1: 200$ & $1: 2,000$ & $\begin{array}{l}\text { Cell Signaling Technology, USA, } \\
\text { Cat. \#5741 }\end{array}$ \\
\hline Catalase, human & Rabbit, monoclonal & - & $1: 2,000$ & Abcam, UK, Cat. \#ab76024 \\
\hline SOD2, human & Rabbit, monoclonal & - & $1 ; 1,000$ & Abcam, UK, Cat. \#ab68155 \\
\hline
\end{tabular}

Table 3: List of secondary antibodies and counterstaining of nuclei

\begin{tabular}{|c|c|c|c|c|}
\hline Secondary detection system used & Host & Method & Dilution & Supplier \\
\hline Anti-Mouse-IgG (H+L)-HRP & Goat & WB & $1: 10,000$ & Sungene Biotech, China, Cat. \#LK2003 \\
\hline Anti-Rabbit-IgG (H+L)-HRP & Goat & WB & $1: 10,000$ & Sungene Biotech, China, Cat. \#LK2001 \\
\hline $\begin{array}{l}\text { Anti-rabbit IgG }(\mathrm{H}+\mathrm{L}), \\
\mathrm{F}(\mathrm{ab}) 2 \text { Fragment (Alexa } \\
\text { Fluor }{ }^{\circledR} 488 \text { Conjugate) }\end{array}$ & Goat & IF & $1: 50$ & Cell Signaling Technology, USA, Cat. \#4412 \\
\hline $\begin{array}{l}\text { Anti-rabbit IgG }(\mathrm{H}+\mathrm{L}), \\
\mathrm{F}(\mathrm{ab}) 2 \text { Fragment (Alexa } \\
\text { Fluor }{ }^{\circledR} 555 \text { Conjugate) }\end{array}$ & Goat & IF & $1: 50$ & Cell Signaling Technology, USA, Cat. \#4413 \\
\hline $\begin{array}{l}\text { Anti-mouse IgG }(\mathrm{H}+\mathrm{L}), \\
\mathrm{F}(\mathrm{ab}) 2 \text { Fragment (Alexa } \\
\text { Fluor }{ }^{\circledR} 488 \text { Conjugate) }\end{array}$ & Goat & IF & $1: 50$ & Cell Signaling Technology, USA, Cat. \#4407 \\
\hline $\begin{array}{l}\text { Anti-mouse IgG }(\mathrm{H}+\mathrm{L}) \text {, } \\
\text { F(ab')2 Fragment (Alexa } \\
\text { Fluor }{ }^{\circledR} 555 \text { Conjugate) }\end{array}$ & Goat & IF & $1: 50$ & Cell Signaling Technology, USA, Cat. \#4408 \\
\hline $\begin{array}{l}\text { Hoechst } 33342 \text { nucleic acid staining } \\
\text { (DAPI) }\end{array}$ & - & IF & $1: 750$ & $\begin{array}{l}\text { Molecular Probes/Invitrogen, Carlsbad, CA, } \\
\text { USA, Cat. \#A11007 }\end{array}$ \\
\hline TOTO-3 iodide & - & IF & $1: 750$ & $\begin{array}{l}\text { Molecular Probes/Invitrogen, Carlsbad, CA, } \\
\text { USA, Cat. \#T3604 }\end{array}$ \\
\hline
\end{tabular}

for $2 \mathrm{~h}$ at room temperature, washed three times with PBS, and incubated with Cy3-labeled or FITC- labeled secondary antibody (Table 3) for $1 \mathrm{~h}$. Nuclei were visualized with $1 \mathrm{mM}$ TOTO-3 iodide for $10 \mathrm{~min}$ at room temperature. Immunofluorescence staining was analyzed using a confocal microscope (Leica, Cat. \#SP8).

\section{Xenograft model}

Male NOD/SCID mice were purchased from Beijing HFK Bioscience Co., Ltd. in Beijing, China. Six mice at Day 42 were subcutaneously injected with T24 cells at a concentration of $4 \times 10^{7} / \mathrm{ml}$ diluted in PBS $(100 \mu \mathrm{l}$ for each mouse) and grown for 14 days [75]. Three mice of them were intraperitoneally injected by carvacrol at $50 \mathrm{mg} / \mathrm{ml}(200 \mu \mathrm{l}$ for each mouse) and repeated for 28 days to inhibit activity of TRPM7 [69]. The other three mice were treated by $0.9 \%$ saline (200 $\mu \mathrm{l}$ for each mouse) for 28 days as control.

Lentiviral-TRPM7-shRNA and lentiviral-controlshRNA infected T24 cells were subcutaneously injected to ten mice, respectively, diluted in PBS ( $200 \mu$ per mouse) at a concentration of $2 \times 10^{7} / \mathrm{ml}$ cells. The tumor size for each mouse was measured every four days using a caliper and counted as: tumor size $=$ length $\times$ width $^{2} \times 0.5 \mathrm{~mm}^{3}$ [76]. The growth of the tumor was observed for 42 days, and the mice was sacrificed to measure the tumor weight. 


\section{Statistical analyses}

Data were expressed as mean \pm SD from three independent experiments. All analyses were performed three times and represent data from three individual experiments. Two-tailed Student's $t$-tests and one-way analysis of variance (ANOVA) were used to evaluate the statistical significance of differences of the data. All of the statistical analyses were performed with SPSS16.0. The statistical significance was set at probability values of $p<0.05$.

\section{ACKNOWLEDGMENTS}

The excellent technical assistance of Yuan Zhu, Mingxia Liao, Shanshan Zhang and Danni Shan is gratefully acknowledged. We thank Professor Loren W. Runnels at University of Medicine \& Dentistry of New Jersey, USA, to kindly provide us the pcDNA5/FRT/TO/ HA-TRPM7 vector.

\section{CONFLICTS OF INTEREST}

The authors declare no potential conflicts of interest.

\section{GRANT SUPPORT}

This study was supported in part by grants from the Wuhan Clinical Cancer Research Center of Urology and Male Reproduction (grant number 303-230100055 to Xinghuan Wang) and Fundamental Research Funds for the Central Universities (grant number 2042015kf0191 to Tongzu Liu and 2042016kf0109 to Zhe Meng). The funders had no role in study design, data collection and analysis, decision to publish, or preparation of the manuscript.

\section{REFERENCES}

1. Burger M, Catto JW, Dalbagni G, Grossman HB, Herr H, Karakiewicz P, Kassouf W, Kiemeney LA, La Vecchia C, Shariat S, Lotan Y. Epidemiology and risk factors of urothelial bladder cancer. Eur Urol. 2013; 63:234-241.

2. Wang G, Wang Y, Cao R, Qian G, Wang X, Xiao Y. Simvastatin induces cell cycle arrest and inhibites proliferation of bladder cancer cells via PPAR and ErbB signaling pathways. 41st American Society of Andrology Annual Meeting, 1-5 April, 2016 (New Orleans, Louisiana, USA). Andrology. 2016; 4:121.

3. Gupta J, Igea A, Papaioannou M, Lopez-Casas PP, Llonch E, Hidalgo M, Gorgoulis VG, Nebreda AR. Pharmacological inhibition of p38 MAPK reduces tumor growth in patientderived xenografts from colon tumors. Oncotarget. 2015; 6:8539-8551. doi: 10.18632/oncotarget.3816.
4. Miguel JC, Maxwell AA, Hsieh JJ, Harnisch LC, Al Alam D, Polk DB, Lien CL, Watson AJ, Frey MR. Epidermal growth factor suppresses intestinal epithelial cell shedding via a MAPK dependent pathway. J Cell Sci. 2016; pii: jcs. 182584.

5. Ge X, Liu J, Shi Z, Jing L, Yu N, Zhang X, Jiao Y, Wang Y, Li PA. Inhibition of MAPK signaling pathways enhances cell death induced by 5-Aminolevulinic acid-photodynamic therapy in skin squamous carcinoma cells. Eur J Dermato. 2016; 26:164-172.

6. Sun X, Deng QF, Liang ZF, Zhang ZQ, Zhao L, Geng H, Xie DD, Wang Y, Yu DX, Zhong CY. Curcumin reverses benzidine-induced cell proliferation by suppressing ERK1/2 pathway in human bladder cancer T24 cells. Exp Toxicol Pathol. 2016; 68:215-222.

7. Zhao B, Li X. Altholactone induces reactive oxygen speciesmediated apoptosis in bladder cancer T24 cells through mitochondrial dysfunction, MAPK-p38 activation and Akt suppression. Oncol Rep. 2014; 31:2769-2775.

8. Improta-Brears T, Whorton AR, Codazzi F, York JD, Meyer T, McDonnell DP. Estrogen-induced activation of mitogenactivated protein kinase requires mobilization of intracellular calcium. Proc Natl Acad Sci USA. 1999; 96:4686-4691.

9. You J, Reilly GC, Zhen X, Yellowley CE, Chen Q, Donahue HJ, Jacobs CR. Osteopontin gene regulation by oscillatory fluid flow via intracellular calcium mobilization and activation of mitogen-activated protein kinase in MC3T3-E1 osteoblasts. J Biol Chem. 2001; 276:13365-13371.

10. Kavanagh BD, Dent P, Schmidt-Ullrich RK, Chen P, Mikkelsen RB. Calcium-dependent stimulation of mitogenactivated protein kinase activity in A431 cells by low doses of ionizing radiation. Radiat Res. 1998; 149:579-587.

11. Wen Y, Alshikho MJ, Herbert MR. Pathway Network Analyses for Autism Reveal Multisystem Involvement, Major Overlaps with Other Diseases and Convergence upon MAPK and Calcium Signaling. PloS one. 2016; 11:e0153329.

12. Favata MF, Horiuchi KY, Manos EJ, Daulerio AJ, Stradley DA, Feeser WS, Van Dyk DE, Pitts WJ, Earl RA, Hobbs F, Copeland RA, Magolda RL, Scherle PA, et al. Identification of a novel inhibitor of mitogen-activated protein kinase kinase. J Biol Chem. 1998; 273:18623-18632.

13. Malemud CJ, Lewis AC, Wylie MA, Meszaros EC, Skomorovska-Prokvolit Y, Mesiano S. U0126, an Inhibitor of MEK1/2, Increases Tumor Necrosis Factor-alpha-Induced Apoptosis, but not Interleukin-6 Induced Apoptosis in C-28/ I2 Human Chondrocytes. J Autoimmune Disord. 2015; 1.

14. Si L, Zheng L, Xu L, Yin L, Han X, Qi Y, Xu Y, Wang C, Peng J. Dioscin suppresses human laryngeal cancer cells growth via induction of cell-cycle arrest and MAPKmediated mitochondrial-derived apoptosis and inhibition of tumor invasion. Eur J Pharmacol. 2016; 774:105-117.

15. Yang F, Tang XY, Liu H, Jiang ZW. Inhibition of mitogenactivated protein kinase signaling pathway sensitizes 
breast cancer cells to endoplasmic reticulum stress-induced apoptosis. Oncol Rep. 2016; 35:2113-2120.

16. Cahalan MD. Cell biology. Channels as enzymes. Nature. 2001; 411:542-543.

17. Levitan IB, Cibulsky SM. Biochemistry. TRP ion channels-two proteins in one. Science. 2001; 293:1270-1271.

18. Paravicini TM, Chubanov V, Gudermann T. TRPM7: a unique channel involved in magnesium homeostasis. Int $\mathrm{J}$ Biochem Cell Biol. 2012; 44:1381-1384.

19. Nadler MJ, Hermosura MC, Inabe $K$, Perraud AL, Zhu Q, Stokes AJ, Kurosaki T, Kinet JP, Penner R, Scharenberg AM, Fleig A. LTRPC7 is a Mg.ATP-regulated divalent cation channel required for cell viability. Nature. 2001; 411:590-595.

20. Aarts $M$, Iihara K, Wei WL, Xiong ZG, Arundine M, Cerwinski W, MacDonald JF, Tymianski M. A key role for TRPM7 channels in anoxic neuronal death. Cell. 2003; 115:863-877.

21. Clark K, Langeslag $M$, van Leeuwen B, Ran L, Ryazanov AG, Figdor CG, Moolenaar WH, Jalink K and van Leeuwen FN. TRPM7, a novel regulator of actomyosin contractility and cell adhesion. EMBO J. 2006; 25:290-301.

22. Hanano T, Hara Y, Shi J, Morita H, Umebayashi C, Mori E, Sumimoto H, Ito Y, Mori Y, Inoue R. Involvement of TRPM7 in cell growth as a spontaneously activated Ca2+ entry pathway in human retinoblastoma cells. J Pharmacol Sci. 2004; 95:403-419.

23. Kim BJ, Nah SY, Jeon JH, So I, Kim SJ. Transient receptor potential melastatin 7 channels are involved in ginsenoside Rg3-induced apoptosis in gastric cancer cells. Basic Clin Pharmacol Toxicol. 2011; 109:233-239.

24. Guilbert A, Gautier M, Dhennin-Duthille I, Haren N, Sevestre H, Ouadid-Ahidouch H. Evidence that TRPM7 is required for breast cancer cell proliferation. Am J Physiol Cell Physiol. 2009; 297:C493-502.

25. Meng X, Cai C, Wu J, Cai S, Ye C, Chen H, Yang Z, Zeng H, Shen Q, Zou F. TRPM7 mediates breast cancer cell migration and invasion through the MAPK pathway. Cancer Lett. 2013; 333:96-102.

26. Davis FM, Azimi I, Faville RA, Peters AA, Jalink K, Putney JW, Jr., Goodhill GJ, Thompson EW, RobertsThomson SJ, Monteith GR. Induction of epithelialmesenchymal transition (EMT) in breast cancer cells is calcium signal dependent. Oncogene. 2014; 33:2307-2316.

27. Middelbeek J, Kuipers AJ, Henneman L, Visser D, Eidhof I, van Horssen R, Wieringa B, Canisius SV, Zwart W, Wessels LF, Sweep FC, Bult P, Span PN, et al. TRPM7 is required for breast tumor cell metastasis. Cancer Res. 2012; 72:4250-4261.

28. Chen JP, Luan Y, You CX, Chen XH, Luo RC, Li R. TRPM7 regulates the migration of human nasopharyngeal carcinoma cell by mediating $\mathrm{Ca}(2+)$ influx. Cell Calcium. 2010; 47:425-432.
29. Rybarczyk P, Gautier M, Hague F, Dhennin-Duthille I, Chatelain D, Kerr-Conte J, Pattou F, Regimbeau JM, Sevestre H, Ouadid-Ahidouch H. Transient receptor potential melastatin-related 7 channel is overexpressed in human pancreatic ductal adenocarcinomas and regulates human pancreatic cancer cell migration. Int J Cancer. 2012; 131:E851-861.

30. Sun Y, Selvaraj S, Varma A, Derry S, Sahmoun AE, Singh BB. Increase in serum $\mathrm{Ca} 2+/ \mathrm{Mg} 2+$ ratio promotes proliferation of prostate cancer cells by activating TRPM7 channels. J Biol Chem. 2013; 288:255-263.

31. Wang J, Xiao L, Luo CH, Zhou H, Hu J, Tang YX, Fang KN, Zhang Y. Overexpression of TRPM7 is associated with poor prognosis in human ovarian carcinoma. Asian Pac J Cancer Prev. 2014; 15:3955-3958.

32. Wang Y, Yang Z, Meng Z, Cao H, Zhu G, Liu T, Wang X. Knockdown of TRPM8 suppresses cancer malignancy and enhances epirubicin-induced apoptosis in human osteosarcoma cells. Int J Biol Sci. 2013; 10:90-102.

33. Yang Z, Wang X, Zhu G, Zhou Z, Wang Y, Chen D, Meng Z. Effect of surgical castration on expression of TRPM8 in urogenital tract of male rats. Mol Biol Rep. 2012; 39: 4797-4802.

34. Meng Z, Cao R, Wang Y, Cao H, Liu T, Yang Z, Wang $X$. Suppression of renal TRPM7 may alleviate kidney injury in the renal transplantation. World J Urol. 2014; 32: 1303-1311.

35. Zhang Z, Faouzi M, Huang J, Geerts D, Yu H, Fleig A, Penner R. N-Myc-induced up-regulation of TRPM6/TRPM7 channels promotes neuroblastoma cell proliferation. Oncotarget. 2014; 5:7625-7634. doi: 10.18632/oncotarget.2283.

36. Iskender $\mathrm{B}$, Izgi $\mathrm{K}$, Hizar $\mathrm{E}$, Jauch J, Arslanhan A, Yuksek EH, Canatan H. Inhibition of epithelialmesenchymal transition in bladder cancer cells via modulation of mTOR signalling. Tumour Biol. 2015; 37:8281-8291.

37. Chen HC, Su LT, Gonzalez-Pagan O, Overton JD, Runnels LW. A key role for $\mathrm{Mg}(2+)$ in TRPM7's control of ROS levels during cell stress. Biochem J. 2012; 445: 441-448.

38. Kamiya $\mathrm{T}$, Goto A, Kurokawa E, Hara H, Adachi T. Cross Talk Mechanism among EMT, ROS, and Histone Acetylation in Phorbol Ester-Treated Human Breast Cancer MCF-7 Cells. Oxid Med Cell Longev. 2016; $2016: 1284372$.

39. Everaerts W, Vriens J, Owsianik G, Appendino G, Voets T, De Ridder D, Nilius B. Functional characterization of transient receptor potential channels in mouse urothelial cells. Am J Physiol Renal Physiol. 2010; 298:F692-701.

40. Shabir S, Cross W, Kirkwood LA, Pearson JF, Appleby PA, Walker D, Eardley I, Southgate J. Functional expression of purinergic $\mathrm{P} 2$ receptors and transient receptor potential channels by the human urothelium. Am J Physiol Renal Physiol. 2013; 305:F396-406. 
41. Mizuno H, Suzuki Y, Watanabe M, Sokabe T, Yamamoto T, Hattori R, Gotoh M, Tominaga M. Potential role of transient receptor potential (TRP) channels in bladder cancer cells. J Physiol Sci. 2014; 64:305-314.

42. Fu QF, Liu Y, Fan Y, Hua SN, Qu HY, Dong SW, Li RL, Zhao MY, Zhen Y, Yu XL, Chen YY, Luo RC, Li R, et al. Alpha-enolase promotes cell glycolysis, growth, migration, and invasion in non-small cell lung cancer through FAKmediated PI3K/AKT pathway. J Hematol Oncol. 2015; 8:22.

43. Liao JM, Cao B, Deng J, Zhou X, Strong M, Zeng S, Xiong J, Flemington E, Lu H. TFIIS.h, a new target of p53, regulates transcription efficiency of pro-apoptotic bax gene. Sci Rep. 2016; 6:23542.

44. Mignard V, Lalier L, Paris F, Vallette FM. Bioactive lipids and the control of Bax pro-apoptotic activity. Cell Death Dis. 2014; 5:e1266.

45. Merino D, Lok SW, Visvader JE, Lindeman GJ. Targeting BCL-2 to enhance vulnerability to therapy in estrogen receptorpositive breast cancer. Oncogene. 2016; 35:1877-1887.

46. Green DR, Llambi F. Cell Death Signaling. Cold Spring Harb Perspect Biol. 2015; 7.

47. Li J, Chen F, Chen Y, Wang Z. Mitochondrial- and FasL-mediated pathways involved in quinestrol induced spermatogenic apoptosis in adult rat testes. Toxicol Mech Methods. 2014; 24:609-615.

48. Babbitt SE, Sutherland MC, San Francisco B, Mendez DL, Kranz RG. Mitochondrial cytochrome c biogenesis: no longer an enigma. Trends Biochem Sci. 2015; 40:446-455.

49. Liu Z, Wu H, Wei Z, Wang X, Shen P, Wang S, Wang A, Chen W, Lu Y. TRPM8: a potential target for cancer treatment. J Cancer Res Clin Oncol. 2016; 142:1871-1881.

50. Trapani V, Arduini D, Cittadini A, Wolf FI. From magnesium to magnesium transporters in cancer: TRPM7, a novel signature in tumour development. Magnes Res. 2013; 26:149-155.

51. Yang ZH, Wang XH, Wang HP, Hu LQ. Effects of TRPM8 on the proliferation and motility of prostate cancer PC-3 cells. Asian J Androl. 2009; 11:157-165.

52. Hatefi N, Nouraee N, Parvin M, Ziaee SA, Mowla SJ. Evaluating the expression of oct4 as a prognostic tumor marker in bladder cancer. Iran J Basic Med Sci. 2012; 15:1154-1161.

53. Amini S, Fathi F, Mobalegi J, Sofimajidpour H, Ghadimi T. The expressions of stem cell markers: Oct4, Nanog, Sox2, nucleostemin, Bmi, Zfx, Tcl1, Tbx3, Dppa4, and Esrrb in bladder, colon, and prostate cancer, and certain cancer cell lines. Anat Cell Biol. 2014; 47:1-11.

54. Huang L, Wu RL, Xu AM. Epithelial-mesenchymal transition in gastric cancer. Am J Transl Res. 2015; 7: 2141-2158.

55. Wei SC, Fattet L, Yang J. The forces behind EMT and tumor metastasis. Cell Cycle. 2015; 14:2387-2388.

56. van Vuurden DG, Aronica E, Hulleman E, Wedekind LE, Biesmans D, Malekzadeh A, Bugiani M, Geerts D,
Noske DP, Vandertop WP, Kaspers GJ, Cloos J, Wurdinger T and van der Stoop PP. Pre-B-cell leukemia homeobox interacting protein 1 is overexpressed in astrocytoma and promotes tumor cell growth and migration. Neuro Oncol. 2014; 16:946-959.

57. Dwyer SF, Gelman IH. Cross-Phosphorylation and Interaction between Src/FAK and MAPKAP5/PRAK in Early Focal Adhesions Controls Cell Motility. J Cancer Biol Res. 2014; 2.

58. Song J, Peng P, Chang J, Liu MM, Yu JM, Zhou L, Sun X. Selective non-zinc binding MMP-2 inhibitors: Novel benzamide Ilomastat analogs with anti-tumor metastasis. Bioorg Med Chem Lett. 2016; 26:2174-2178.

59. Jablonska-Trypuc A, Matejczyk M, Rosochacki S. Matrix metalloproteinases (MMPs), the main extracellular matrix (ECM) enzymes in collagen degradation, as a target for anticancer drugs. J Enzyme Inhib Med Chem. 2016:1-7.

60. Yang SX, Polley E, Lipkowitz S. New insights on PI3K/ AKT pathway alterations and clinical outcomes in breast cancer. Cancer Treat Rev. 2016; 45:87-96.

61. Robbins HL, Hague A. The PI3K/Akt Pathway in Tumors of Endocrine Tissues. Front Endocrinol (Lausanne). 2015; 6:188.

62. Jafarinejad-Farsangi S, Farazmand A, Mahmoudi M, Gharibdoost F, Karimizadeh E, Noorbakhsh F, Faridani H, Jamshidi AR. MicroRNA-29a induces apoptosis via increasing the Bax:Bcl-2 ratio in dermal fibroblasts of patients with systemic sclerosis. Autoimmunity. 2015; 48:369-378.

63. Mukherjee A, Khuda-Bukhsh AR. Quercetin Downregulates IL-6/STAT-3 Signals to Induce Mitochondrialmediated Apoptosis in a Nonsmall- cell Lung-cancer Cell Line, A549. J Pharmacopuncture. 2015; 18:19-26.

64. Dolka I, Krol M, Sapierzynski R. Evaluation of apoptosisassociated protein (Bcl-2, Bax, cleaved caspase-3 and p53) expression in canine mammary tumors: An immunohistochemical and prognostic study. Res Vet Sci. 2016; 105:124-133.

65. Jiang W, Luo T, Li S, Zhou Y, Shen XY, He F, Xu J, Wang HQ. Quercetin Protects against Okadaic AcidInduced Injury via MAPK and PI3K/Akt/GSK3beta Signaling Pathways in HT22 Hippocampal Neurons. PloS one. 2016; $11: \mathrm{e} 0152371$.

66. Wang X, Xu W, Fan M, Meng T, Chen X, Jiang Y, Zhu D, $\mathrm{Hu}$ W, Gong J, Feng S, Wu J, Li Y. Deoxynivalenol induces apoptosis in PC12 cells via the mitochondrial pathway. Environ Toxicol Pharmacol. 2016; 43:193-202.

67. Yang J, Yao S. JNK-Bcl-2/Bcl-xL-Bax/Bak Pathway Mediates the Crosstalk between Matrine-Induced Autophagy and Apoptosis via Interplay with Beclin 1. Int J Mol Sci. 2015; 16:25744-25758.

68. Cagnol S, Chambard JC. ERK and cell death: mechanisms of ERK-induced cell death-apoptosis, autophagy and senescence. FEBS J. 2010; 277:2-21.

69. Chen WL, Barszczyk A, Turlova E, Deurloo M, Liu B, Yang BB, Rutka JT, Feng ZP, Sun HS. Inhibition of TRPM7 
by carvacrol suppresses glioblastoma cell proliferation, migration and invasion. Oncotarget. 2015; 6:16321-16340. doi: 10.18632/oncotarget.3872.

70. Yu W, Zhang Y, Xu L, Sun S, Jiang X, Zhang F. Microarraybased bioinformatics analysis of osteoblasts on $\mathrm{TiO} 2$ nanotube layers. Colloids Surf B Biointerfaces. 2012; 93:135-142.

71. Dennis G, Jr., Sherman BT, Hosack DA, Yang J, Gao W, Lane HC, Lempicki RA. DAVID: Database for Annotation, Visualization, and Integrated Discovery. Genome Biol. 2003; 4:P3.

72. Su LT, Agapito MA, Li M, Simonson WT, Huttenlocher A, Habas R, Yue L, Runnels LW. TRPM7 regulates cell adhesion by controlling the calcium-dependent protease calpain. J Biol Chem. 2006; 281:11260-11270.

73. Noh KW, Park J, Joo EH, Lee EK, Choi EY, Kang MS. ERK2 phosphorylation of EBNA1 serine 383 residue is important for EBNA1-dependent transactivation. Oncotarget. 2016; 7:25507-25515. doi: 10.18632/ oncotarget.8177.

74. Yoshimi Y, Kunimatsu R, Hirose N, Awada T, Miyauchi M, Takata T, Wu L, Zhu L, Denbesten P, Tanne K, Tanimoto K. Effects of C-Terminal Amelogenin Peptide on the Proliferation of Human Cementoblast Lineage Cells. J Periodontol. 2016:1-20.

75. Yang ZH, Wang XH, Wang HP, Hu LQ, Zheng XM, Li SW. Capsaicin mediates cell death in bladder cancer T24 cells through reactive oxygen species production and mitochondrial depolarization. Urology. 2010; 75:735-741.

76. Naito S, von Eschenbach AC, Giavazzi R, Fidler IJ. Growth and metastasis of tumor cells isolated from a human renal cell carcinoma implanted into different organs of nude mice. Cancer Res. 1986; 46:4109-4115. 